\title{
Mitochondrial-DNA Phylogenetic Information and the Reconstruction of Human Population History: The South American Case
}

María Bárbara Postillone ${ }^{1}$ and S. Ivan Perez ${ }^{2}$

\begin{abstract}
Mitochondrial DNA (mtDNA) sequences are becoming increasingly important in the study of human population history. Here, we explore the differences in the amount of information of different mtDNA regions and their utility for the reconstruction of South American population history. We analyzed six data sets comprising 259 mtDNA sequences from South America: Complete mtDNA, Coding, Control, hypervariable region I (HVRI), Control plus cytochrome b (cyt $b$ ), and cyt $b$ plus 12 S plus 16S. The amount of information in each data set was estimated employing several site-by-site and haplotype-based statistics, distances among sequences, neighbor-joining trees, distances among the estimated trees, Bayesian skyline plots, and phylogenetic informativeness profiles. The different mtDNA data sets have different amounts of information to reconstruct demographic events and phylogenetic trees with confidence. Whereas HVRI is not suitable for phylogenetic reconstruction of ancient clades, this region, as well as the Control data set, displays information for the demographic reconstruction during the Holocene period, probably because of the high rate of mutation of these regions. As expected, the Complete mtDNA and Coding data sets, displaying slower rates of mutation, present suitable information to estimate the founding subhaplogroups that populated South America and for the reconstruction of ancient demographic events. Our results point out the importance of evaluating the utility of different DNA regions to respond to different questions and problems in the human population studies, mainly considering the time scale of the phenomenon and the informativeness of the molecular region in a particular geographical area.
\end{abstract}

$\mathrm{M}$ olecular data have become increasingly important during the last century for the study of human population histories. In recent years these studies have been revolutionized by the analysis of genome-scale data sets (Macaulay et al. 2005; Li and Durbin 2011; Rasmussen et al. 2011; Mallick et al. 2016).
In particular, the analysis of mitochondrial DNA (mtDNA) genomes has had a profound impact on studies of the evolution of human populations at global and regional scales. In this context, our understanding of the early dispersion and demographic history of the humans who peopled the Americas, mainly South America, has been

\footnotetext{
${ }^{1}$ Departamento de Ciencias Naturales y Antropológicas, Universidad Maimonides, Centro de Estudios Biomédicos, Biotecnológicos, Ambientales, y de Diagnóstico (CEBBAD), Consejo Nacional de Investigaciones Científicas y Técnicas (CONICET), Buenos Aires, Argentina.

${ }^{2}$ División Antropología, Facultad de Ciencias Naturales y Museo, Universidad Nacional de La Plata, Consejo Nacional de Investigaciones Científicas y Técnicas (CONICET), La Plata, Argentina.

*Correspondence to: S. Ivan Perez, División Antropología, Facultad de Ciencias Naturales y Museo, Universidad Nacional de La Plata, 122 and 60, La Plata 1900, Argentina. E-mail: ivanperezmorea@gmail.com.

KEYWORDS: MOLECULAR DISTANCES, SUBSTITUTION RATES, BAYESIAN METHODS, POPULATION DYNAMICS.
} 
greatly impacted by these analyses (Fagundes et al. 2008b; Perego et al. 2010; Bodner et al. 2012; de Saint Pierre et al. 2012b; Llamas et al. 2016).

Despite many studies using genomic data, migratory and demographic topics are also addressed using mtDNA control region sequences and the nonrecombining region of the Y chromosome (Vigilant et al. 1991; Rubicz et al. 2007; Bisso-Machado et al. 2012; Wallace 2015; Poznik et al. 2016). In particular, several works employ sequences from hypervariable regions I and II (HVRI and HVRII) to explore hypotheses about the origin, migration route, and demographic history of aboriginal human populations that inhabited South America (e.g., Moraga et al. 2000; O'Rourke and Raff 2010; Kemp and Schurr 2010; de Saint Pierre et al. 2012a). More recently, studies exploring human evolution in the subcontinent have analyzed ancient DNA, sequencing mainly HVRI (e.g., Carnese et al. 2010; Fehren-Schmitz et al. 2011, 2014; Mendisco et al. 2014; Postillone et al. 2017). These studies have generated a large comparative database of HVRI and HVRII, as well as a more restricted sample of complete mtDNA genomic data. Therefore, a critical issue is to understand the utility of these different DNA regions or data sets for the study of past human populations in geographical regions as South America.

This is particularly important if we consider that different mtDNA regions display differences in their substitution rate (Endicott and Ho 2008; Soares et al. 2009) and therefore differences in the amount of phylogenetic information (Townsend 2007; Dornburg et al. 2014). The relevant question here is which mtDNA region is more informative about a process or event for a given time interval in the past. Whereas in interspecies studies researchers have long discussed the utility of different mitochondrial and nuclear genomic regions for phylogenetic inference (e.g., Goldman 1998; Graybeal 1998; Yang 1998; Cotton and Wilkinson 2008; Camargo et al. 2012; Dornburg et al. 2014), this problem has been scarcely explored in depth in human population studies (see Non et al. 2007). This is striking because, for example, the different human mtDNA regions are known to differ in their substitution rate and level of saturation (Soares et al. 2009). At present, there is no robust theory predicting the power of DNA regions for a particular time in the past, although the amount of information of a molecular sequence can be empirically quantified (Townsend 2007).

Here, we empirically explored differences in the amount of information of different mtDNA regions and their utility for the reconstruction of human population history. A previous study explored the utility of different mitochondrial genomic regions for phylogenetic inference in the Old World (Non et al. 2007), suggesting that the mtDNA control region has limited utility for the study of the human population history. We statistically address this problem employing samples from South America, a model system that displays a recent human peopling (ca. 15,000-20,000 years ago; Fagundes et al. 2008b; Llamas et al. 2016). Although we explored American sequences, the objective of our work was methodological, having as its goal to understand the performance of different data sets and not the examination of the peopling of America. Specifically, in this work we addressed the impact of variability and informativeness of different mtDNA regions, some of them previously employed in South American studies, on genealogical (i.e., individual phylogeny) and demographic reconstructions. Unlike previous studies, we explicitly explored the impact of differences in the amount of information of different mtDNA regions in the population dynamics estimation at a continental scale, in a model system with a more recent human peopling than previously used (Non et al. 2007). Therefore, we expected our results to differ from previous works. We explored this problem using complete mtDNA genomes, multivariate statistics, and Bayesian methods. We also discuss the best way to employ mtDNA data sets in human population studies. We expect our study to allow for a better use of the large quantity of mtDNA data and to improve genealogical and demographic inferences.

\section{Materials and Methods}

We obtained 259 DNA sequences comprising the whole mitochondrial genome (complete mtDNA) from GenBank and previous publications (Hartmann et al. 2009; Perego et al. 2009, 2010; Bodner et al. 2012; de Saint Pierre et al. 2012b; Llamas et al. 2016). Accession numbers for the mitochondrial sequences from South America are shown in 
Supplementary Table S1. These sequences come from modern and prehistoric humans of South America, particularly from south-central Andes ( $n=123$; Hartmann et al. 2009; Perego et al. 2009, 2010; Bodner et al. 2012; de Saint Pierre et al. 2012b; Llamas et al. 2016), northeastern South America ( $n=17$; Hartmann et al. 2009; Perego et al. 2009, 2010; Bodner et al. 2012; Llamas et al. 2016), and Pampa-Patagonia ( $n=119$; Perego et al. 2009; 2010; Bodner et al. 2012; de Saint Pierre et al. 2012b; Llamas et al. 2016).

The sequences of mitochondrial genomes were aligned in the software MAFFT (version 7.012b; Katoh and Standley 2013), using the algorithm FFT-NS-2, and manually verified with the software BioEdit (version 7.0.0; Hall 2004). After alignment, the complete mtDNA data set was divided in two new data sets, the Control and Coding region data sets (Figure 1), which previously were used in studies about South American human evolution (e.g., de Saint Pierre et al. 2012a; Fagundes et al. 2008b). The Control data set comprises 1,122 base pairs (bp), including positions 1-576 and 16024-16569; the Coding data set comprises 15,391 bp, between the positions 577 and 16023 (with two intercalated noncoding segments of 25 and $31 \mathrm{bp}$; Andrews et al. 1999). We also analyzed only the 343 bp of the HVRI (Figure 1), from position 16024 to position 16365 . Finally, we generated two novel data sets. The first novel data set, Control-cyt $b$, includes the Control region and the 1,140 bp from the cytochrome b (cyt $b$ ) gene (Figure 1; between positions 14747 and 15887). The second novel data set, cyt $b-12 S-16 S$, includes cyt $b$ plus the 12S rRNA (between positions 648 and 1601) and 16S rRNA (between positions 1671 and 3229; Figure 1). We chose these data sets for two reasons: (a) the control, HVRI, and coding regions are widely used in studies of human population and evolution in South America (de Saint Pierre et al. 2012a; Fagundes et al. 2008b; Perez et al. 2016) and represent regions with marked differences in substitution rate and relative number of mutations (Soares et al. 2009); (b) conversely, the cyt $b, 12 \mathrm{~S}$ rRNA, and 16S rRNA regions, as well as the control region plus cyt $b$ gene, are widely used in phylogenetic and biogeographic studies, mainly in analyses involving closely related species and subspecies (e.g., Marín et al. 2008; Lynch Alfaro et al. 2012; Metcalf et al. 2016), and therefore could be

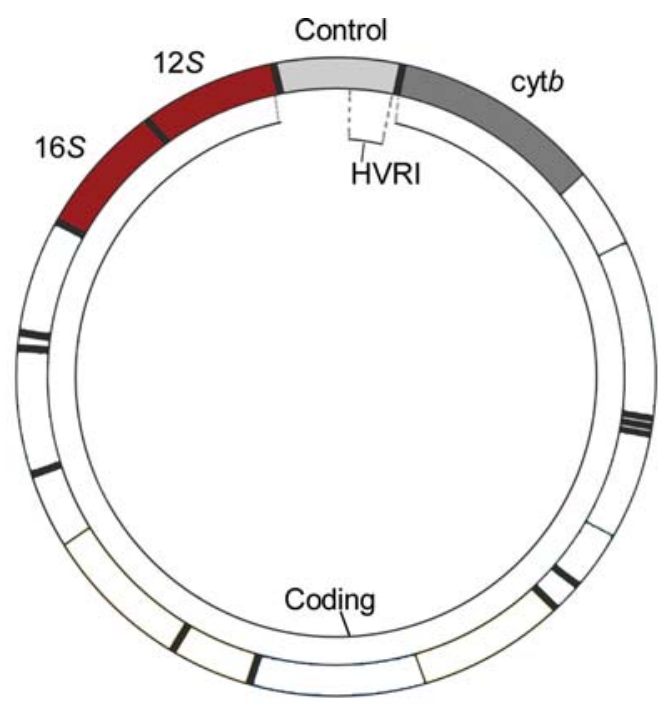

FIGURE 1. Map of the mitochondrial genome highlighting the subregions studied: Coding, Control, hypervariable region I (HVRI), cytochrome b (cytb), 12S, and $16 \mathrm{~S}$. useful for human population studies. All data sets were used in the subsequent analyses.

We first explored the differences among the molecular mtDNA data sets by estimating the similarity between distance matrices and genealogical trees obtained using each data set. We estimated the maximum composite likelihood distance and employed the neighbor-joining method, implemented in MEGA (version 7.0.20; Kumar et al. 2016), to reconstruct the phylogenies. We employed the neighbor-joining method because it is more efficient for large data sets than the alternatives (Tamura et al. 2004). We then compared the matrices of distances and the genealogical trees obtained by calculating the matrix correlation (Smouse et al. 1986; Legendre and Legendre 1998) for the former and the Robinson-Foulds (RF) distance (Robinson and Foulds 1981; Kuhner and Felsenstein 1994) for the latter. To estimate the matrix correlation, the matrices were unfolded into vectors and a simple correlation was calculated. We also estimated dispersion plots, similar to empirical saturation plots (Graybeal 1994), to graphically evaluate the utility of the mtDNA regions to reconstruct a phylogeny. The RF distance or topological congruence between trees was calculated as the number of internal branches observed in one phylogeny but not in the other. The matrix of RF distances was analyzed using two multivariate analyses: the unweighted pair group method with arithmetic mean (UPGMA) cluster and the nonmetric multidimensional scaling (nmMDS). RF distances were calculated in the Tree distance 3.695 program of the PHYLIP package (Felsenstein 2005), whereas 
the matrix correlations and multivariate analyzes were performed in the software PAST (version 3.0; Hammer et al. 2001).

We further described the differences among the molecular mtDNA data sets by calculating several site-by-site and haplotype-based statistics (Rozas 2009). For the site-by-site analyses, we calculated the number of variable positions or segregating sites $(S)$ in each data set. Because this statistic is sensitive to the number of sites in the sequences $\left(N_{s}\right.$; Rozas 2009), we calculated the number of segregating sites on the total number of sites in the sequence $\left(S / N_{s}\right)$. We also estimated the mean number of nucleotide differences between sequences $(k)$ and the average number of nucleotide differences per site or the nucleotide diversity $(\pi)$, defined as $k$ divided by the number of sites in the sequence, excluding the sites with alignment gaps (Rozas 2009). Finally, we estimated the number of different DNA sequences or haplotypes (h) and the mean of the haplotype proportions or haplotype diversity ( $H$; Rozas 2009). Because the definition of haplotypes is related to the number of sites in the sequence $\left(N_{s}\right)$, we estimated the number of haplotypes divided by the number of site in the sequences $\left(h / N_{s}\right)$.

Second, we used the six mtDNA data set to estimate the demographic trajectories of the South American populations employing the Bayesian skyline plot (BSP) method (Drummond et al. 2005) implemented in the software BEAST (version 1.6.1; Drummond and Rambaut 2007). The BSP method uses the shape of a genealogy estimated with molecular data to reconstruct the demographic dynamics of a population in the past (Drummond et al. 2005; Ho and Shapiro 2011). The method simultaneously estimates genealogy, coalescence time, and population size through time using a Markov chain Monte Carlo sampling procedure (Drummond et al. 2005). We used the BEAUti program to set the parameters of the analyses for the data sets. The models of substitution for each mtDNA region or data set were inferred with the Akaike information criterion with correction for sample size implemented in the software jModelTest (version 2.1.10; Guindon and Gascuel 2003; Darriba et al. 2012). The HKY $+\mathrm{I}+\mathrm{G}$ model of mtDNA sequence substitution displayed the best fit for all data sets. The sequences were analyzed under an uncorrelated lognormal relaxed molecular clock model, and we set the tree priors as a coalescent Bayesian skyline. The number of generations was established at 50,000,000 and the sample frequency at 5,000 for the Markov chain Monte Carlo sampling. We employed two widely used substitution rates in South American studies (Fagundes et al. 2008b; de Saint Pierre et al. 2012a; Perez et al. 2016): 3.02E-7 substitutions per site per year (Endicott and Ho 2008) for the control, HVRI, and control plus cytb regions, and 1.26E-08 substitutions per site per year (Fagundes et al. 2008b) for complete mtDNA, cyt $b$ plus $12 S$ plus $16 \mathrm{~S}$, and coding region. The use of ancient DNA can influence our demographic estimations, so we alternatively included and excluded the ancient sequences in the analyses. The BSPs were reconstructed using the estimated genealogies in the software Tracer (version 1.5; Rambaut and Drummond 2007). Tracer also was used to test for the convergence in the parameters of the Bayesian analyses.

Finally, we explicitly tested for the phylogenetic informativeness of the different data sets. We employed the online application PhyDesign (LópezGiráldez and Townsend 2011), which implements the Townsend (2007) phylogenetic informativeness profile. This method provides a quantitative measurement of the utility of a molecular region or data set to reconstruct a phylogeny at different times in the past (Townsend 2007; López-Giráldez and Townsend 2011). Phylogenetic informativeness relates nucleotide saturation in a molecular region to the estimated divergence time (Townsend 2007; Dornburg et al. 2014). Specifically, the informativeness profile is estimated based on the ratio of the observed rate of substitution to the optimal rate of substitution for genealogical inference at different times in the past (Dornburg et al. 2014).

\section{Results}

The relationships among mtDNA lineages estimated by the neighbor-joining trees are similar for the Complete mtDNA, Control, Control-cytb, and Coding data sets (Figure 2). The complete mtDNA tree shows that haplogroup B, including the subhaplogroups B2 and B2i, is related to subhaplogroup A2. Haplogroup D displays large variability and shows four well-defined clades or subhaplogroups (note that we use the terms 
haplogroup, subhaplogroup, and haplotype only as a convenience in this work; for a broader discussion of the terminology, see Kemp and Schurr 2010), all of them monophyletic (D1, D4h3, Dlg, and Dlj). The tree also displays large diversity in haplogroup C, showing the monophyly of subhaplogroups $\mathrm{Clb}$, Clc, and Cld. The trees based on the Control and Control-cyt $b$ data sets display slight differences from the Complete mtDNA tree. In particular, in these data sets some subhaplogroups, such as D1 and D4h3, are not monophyletic. Conversely, the trees based on HVRI and cyt $b-12 S-16 S$ data sets display large differences. In particular, the HVRI shows that almost all the subhaplogroups are not monophyletic, displaying different relationships among them. Finally, the tree based on the Coding data set displays some similarities with the Complete mtDNA tree, showing only subhaplogroups Dlg and B2 as polyphyletic.

The pattern of similarity between the data sets can be better observed in the nmMDS (stress $=0$ ) and UPGMA results (Figure 3 ). These results confirm that the Control and Control-cyt $b$ data sets generate trees more similar to the Complete mtDNA tree, whereas the HVRI and cyt $b-12 S-16 S$ trees display large differences compared to each other and to the Complete mtDNA tree. We also explored the variation in a data set displaying sequences from all America, including the 259 South American sequences and 174 sequences from North America (Supplementary Table S2; Just et al. 2008; Hartmann et al. 2009; Perego et al. 2009, 2010; Achilli et al. 2013; Llamas et al. 2016), to compare with the South American case. The results show a pattern of differences among the mtDNA data sets for the American sample (Supplementary Figure S1) that is similar to the pattern observed for the South American sample, suggesting that our results could be generalized to the entire peopling of America. When we observed the correlations between distance matrices (Table 1), the Control, Control-cyt $b$, and Coding data sets show correlations between 0.90 and 0.98 , whereas the cyt $b-12 S-16 S$ and HVRI data sets display correlation values of 0.84 and 0.87 , respectively. Despite the global similarities, the dispersion plot showed in Figure 4 graphically suggests that the HVRI and Control data sets change at a much higher rate than do the Complete mtDNA, Coding, and cyt $b-12 S-16 S$ data sets.
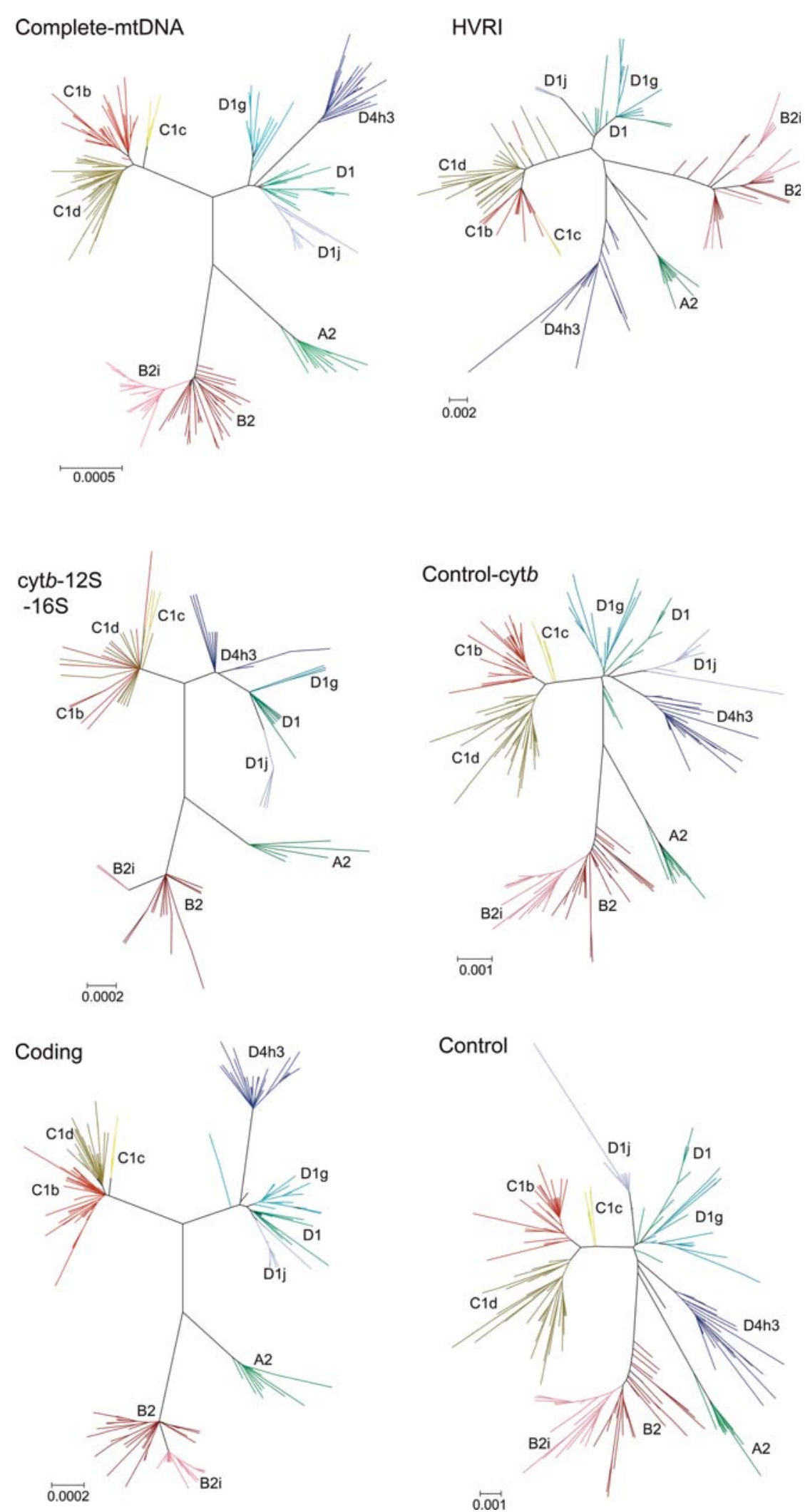

FIGURE 2. Phylogenetic trees estimated employing the neighbor-joining method and the maximum composite likelihood distance for each data set. 
FIGURE 3. Nonmetric multidimensional scaling (nmMDS) and unweighted pair group method with arithmetic mean (UPGMA) cluster analyses of topological differences among the phylogenetic trees depicted in Figure 2. The analyses used the Robinson-Foulds (RF) distance to estimate the similarity between the data sets.
FIGURE 4. Relationships between the Complete mtDNA and other mtDNA data sets.

Table 1. Correlation and Significance Values between mtDNA Regions for All the South American Haplogroups

\begin{tabular}{|l|c|c|c|c|c|c|} 
& Complete mtDNA & Coding & Control & HVRI & Control-cytb & cytb-12S-16S \\
\hline Complete-mtDNA & - & 0.000 & 0.000 & 0.000 & 0.000 & 0.000 \\
\hline Coding & 0.982 & - & 0.000 & 0.000 & 0.000 & 0.000 \\
\hline Control & 0.895 & 0.798 & - & 0.000 & 0.000 & 0.000 \\
\hline HVRI & 0.875 & 0.812 & 0.897 & - & 0.000 & 0.000 \\
\hline Control-cytb & 0.923 & 0.852 & 0.967 & 0.874 & - & 0.000 \\
\hline cytb-12S-16S & 0.841 & 0.841 & 0.717 & 0.665 & 0.838 & - \\
\hline
\end{tabular}

$\mathrm{nmMDS}$

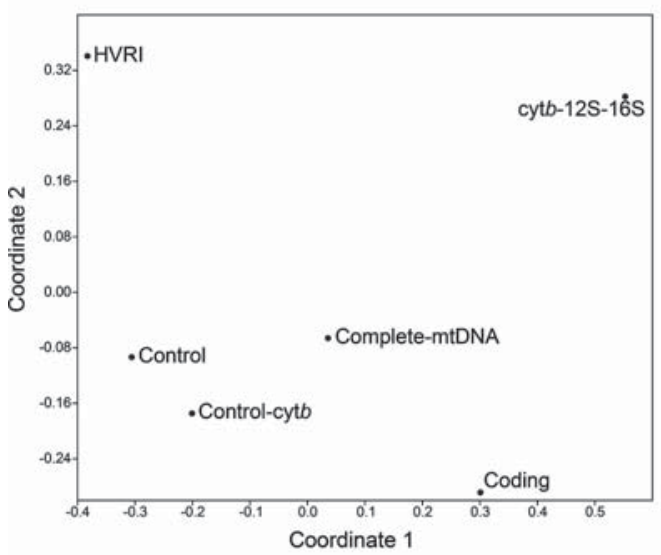

A similar pattern of differences among the data sets arises from the analyses of site-by-site and haplotype variation (Table 2). The number of segregating sites was relatively large in the Complete mtDNA and Coding data sets, intermediate in the Control and HVRI data sets, and low in Control-cyt $b$ and cyt $b-12 S-16 S$ data sets. However, the Control and HVRI data sets display the largest values of proportional segregating sites $\left(S / N_{s}\right)$. We observed the same pattern when we

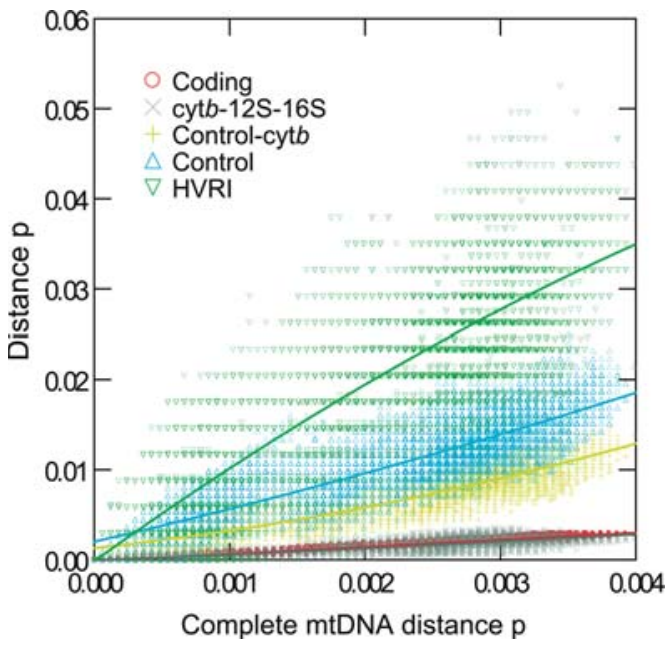

UPGMA

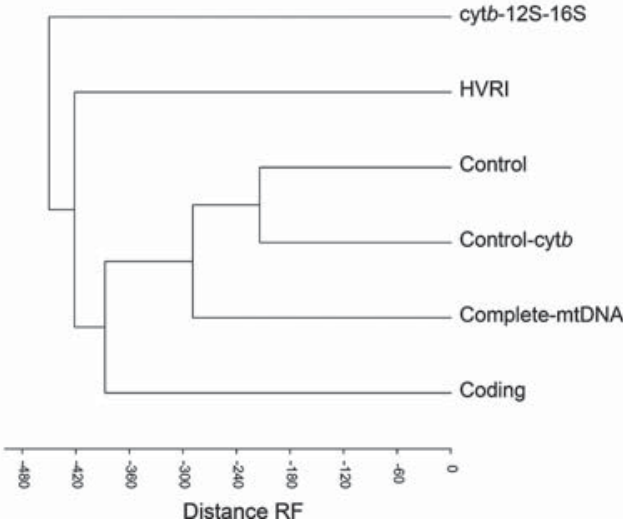

calculated the mean number of nucleotide differences between sequences $(k)$ and the nucleotide diversity or the proportion of $k$ on $N_{s}$ (Table 2). When we consider the haplotype analyses, we also observed a pattern similar to the one we detected in the site-by-site analyses: whereas the Complete mtDNA and Coding data sets display the largest number of haplotypes $(h)$, the Control and HVRI data sets display the largest values of proportional number of haplotypes $\left(h / N_{s}\right)$.

In concordance with the pattern of similarities in sequence variability and rate of substitution, the BSP result displays a clear pattern of differences between data sets. In particular, the noncoding data sets (Control and HVRI) show that the female effective population size was constant from the initial peopling until ca. 7,500 years ago and increased between 7,500 and 4,000 years ago (Figure 5). The Control-cyt $b$ data set result displays a similar pattern of demographic change. Conversely, the Complete mtDNA and Coding data sets show more complex demographic dynamics, with an additional increase in the population size ca. 17,000 years BP (Figure 5). These data sets also display a later increase in population size ca. 5,500 years BP, suggesting that the largest data sets present more 
Table 2. Analysis of Sequence Polymorphism for the mtDNA Data Sets of All South American Haplogroups

\begin{tabular}{|l|c|c|c|c|c|c|c|c|c|c|}
\multicolumn{1}{c|}{ Datasets } & \multicolumn{2}{c|}{ Sample size } & \multicolumn{5}{c|}{ Nucleotide statistics } & \multicolumn{4}{c|}{ Haplotype statistics } \\
& $\boldsymbol{N}$ & $\boldsymbol{N}_{\boldsymbol{s}}$ & $\boldsymbol{S}$ & $\boldsymbol{S} / \mathbf{N}_{\boldsymbol{s}}$ & $\boldsymbol{k}$ & $\boldsymbol{\pi}$ & $\boldsymbol{h}$ & $\boldsymbol{h} / \boldsymbol{h}$-max & $\boldsymbol{h} / \mathbf{N}_{\boldsymbol{s}}$ & $\boldsymbol{H}$ \\
\hline Complete-mtDNA & 259 & 16593 & 643 & 0.039 & 32.066 & 0.002 & 233.000 & 1.000 & 0.014 & 0.999 \\
\hline Coding & 259 & 15450 & 500 & 0.032 & 23.562 & 0.002 & 212.000 & 0.910 & 0.014 & 0.998 \\
\hline Control & 259 & 1144 & 143 & 0.125 & 8.504 & 0.009 & 169.000 & 0.725 & 0.148 & 0.994 \\
\hline HVRI & 259 & 348 & 74 & 0.213 & 4.688 & 0.016 & 108.000 & 0.464 & 0.310 & 0.964 \\
\hline Control-cytb & 259 & 2280 & 198 & 0.087 & 11.641 & 0.006 & 189.000 & 0.811 & 0.083 & 0.996 \\
\hline cytb-12S-16S & 259 & 3648 & 97 & 0.027 & 5.157 & 0.001 & 90.000 & 0.386 & 0.025 & 0.960 \\
\hline
\end{tabular}

$N$ : number of sequences; $N_{s}$ : number of sites; $S$ : number of segregating sites or number of polymorphic sites; $S / N_{s}$ : the proportion of $S$ on $N_{s} ; k$ : mean number of nucleotide differences between sequences; $\pi$ : nucleotide diversity or the proportion of $k$ on $N s ; h$ : number of haplotypes or the different DNA sequences; $h / h$ max: the proportion of $h$ on the maximum value of $h ; h / N_{s}$ : the proportion of $h$ on the number of sites; $H$ : haplotype diversity.

information for demographic studies. The results shown that the exclusion of ancient DNA in the BSP analyses does not influence the demographic estimations (Supplementary Figure S2), although they represent more than the $30 \%$ of the samples used in the database. Perhaps this may relate to

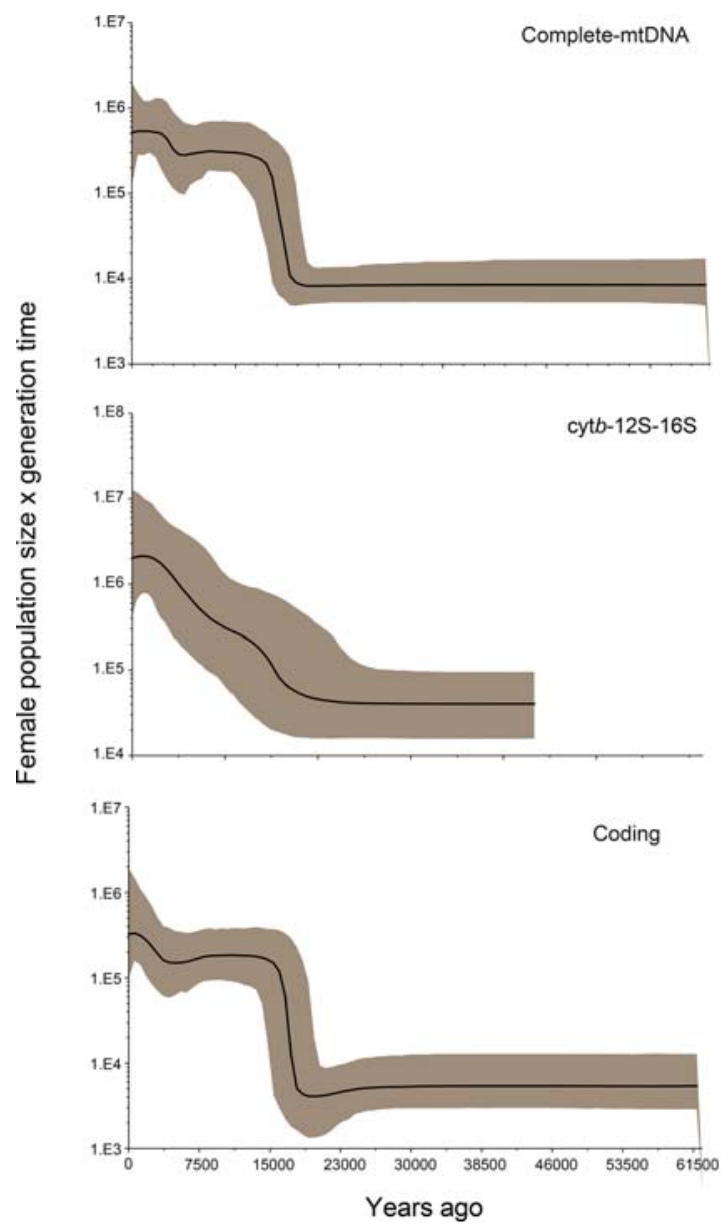

the fact that most of them correspond to the late Holocene (300-700 years BP; Llamas et al. 2016).

Figure 6 displays the results of the informativeness profiles for each data set. The Complete mtDNA and Coding data sets show the largest values of net informativeness in the more distant
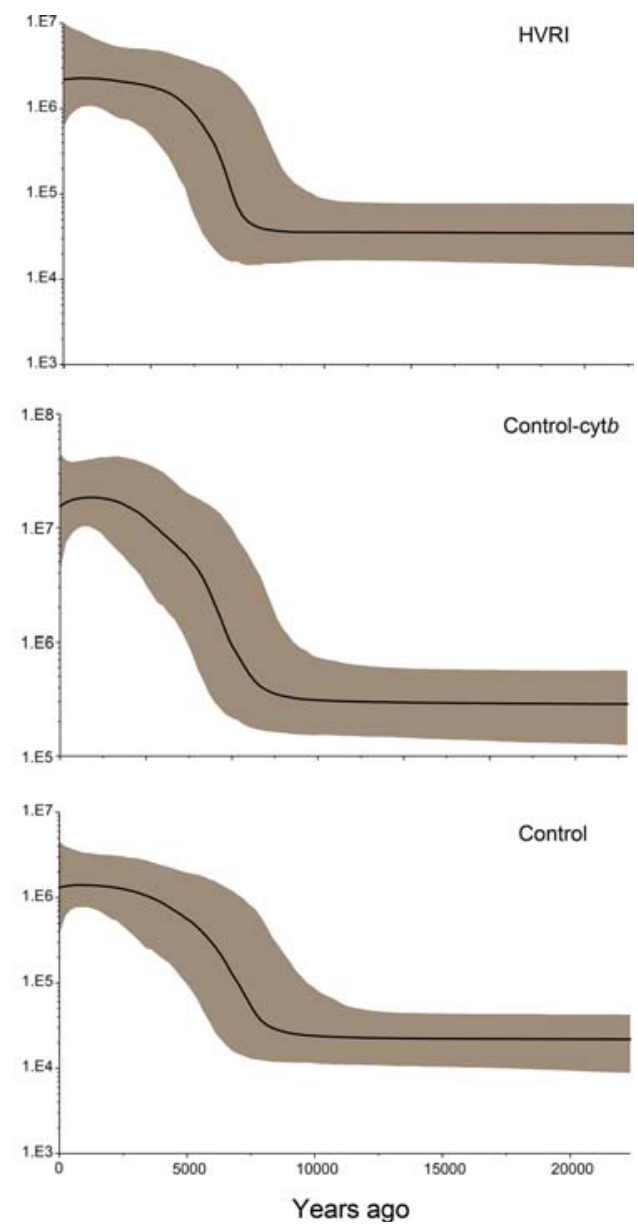

FIGURE 5. Demographic changes in South America estimated based on the molecular sequences of the six data sets studied. The times are scaled. 


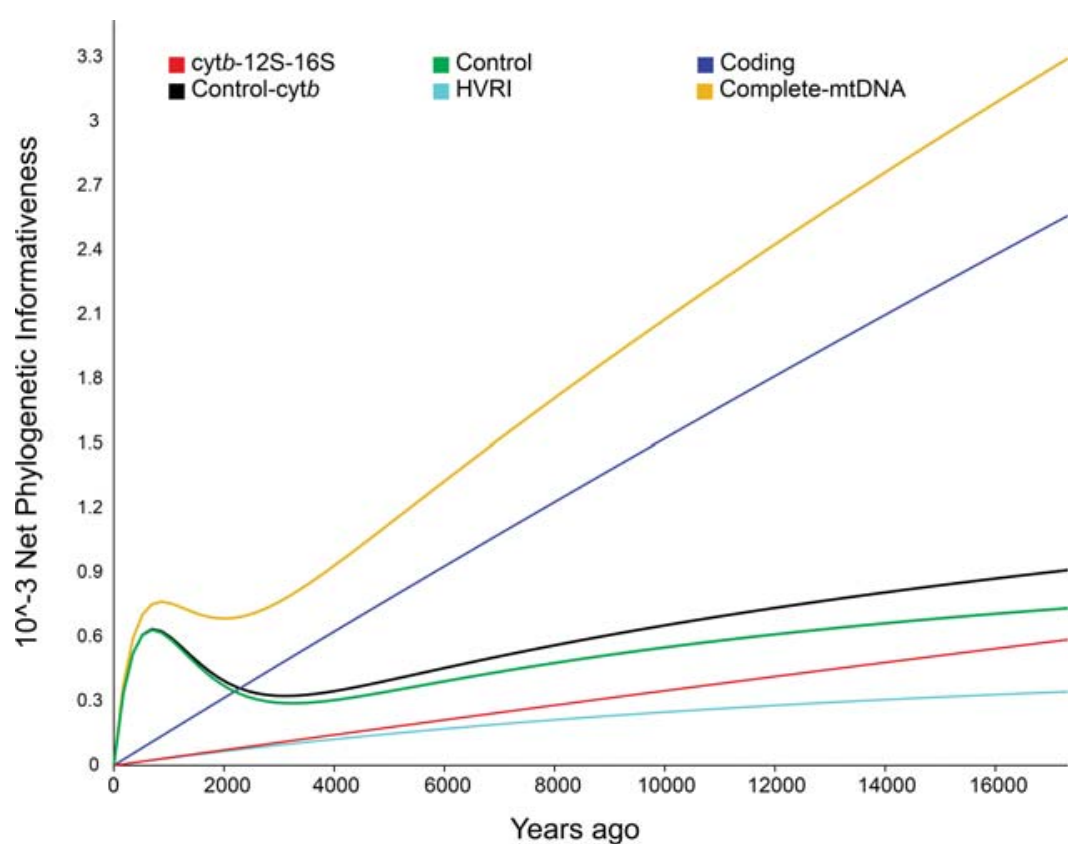

FIGURE 6. Net phylogenetic informativeness profiles of the six data sets studied. past, ca. 17,000 years BP, decaying quickly from that time until the present. The Control and Controlcyt $b$ data sets, together with the Complete mtDNA, display the largest informativeness during the last 2,000 years (Figure 6). The pattern of differences among the data sets observed in the informativeness profiles look similar to that observed in BSP results and in the other analyses, suggesting the importance of considering informativeness estimations in reconstructing population dynamics at different times in the past.

\section{Discussion}

Previous work in the Old World has shown that phylogenetic trees based on the mtDNA control region are poorly resolved (Non et al. 2007). In the same way, the works performed in America have suggested that data sets such as the mtDNA control region - including the HVRI- - have limited utility for studying human population history in the continent (Tamm et al. 2007; Fagundes et al. 2008b; de Saint Pierre et al. 2012b). In particular, these studies have pointed out that the lineage genealogy or phylogeny of the mtDNA variants in America could not be reconstructed using the HVRI or control region, making it difficult to define the founding clades or subhaplogroups that arrived on the continent during the early peopling
(Fagundes et al. 2008a; de Saint Pierre et al. 2012b). More generally, it was suggested that the time and mode of the early American peopling cannot be reconstructed with confidence when the HVRI or control region is used because they both display limited information-mainly due to the small size of these sequences - and high frequency of recurrent mutations (Tamm et al. 2007; Non et al. 2007; Fagundes et al. 2008b). Conversely, previous studies pointed out that the complete coding region and the complete mtDNA should be more appropriate for genealogical reconstruction and the study of population history in America (Tamm et al. 2007; Fagundes et al. 2008a, 2008b; de Saint Pierre et al. 2012b). Many of these studies assume that these large sequences are most useful than the noncoding ones because they present changes that are unique and irreversible (but see Non et al. 2007). This assumption is in line with more general discussions in studies of phylogenetic inference about the utility of unique and irreversible changes versus characters that present recurrent states (Townsend 2007; Yang 1998). To the best of our knowledge, although many statistics have been generated to measure the utility of different sequence data in phylogenetic inference, there have been few systematic explorations of this problem in anthropological studies (Non et al. 2007), and there has been no systematic research at small temporal scales, such as the observed in the South American peopling.

Contrary to suggestions of previous studies, our results display a complex scenario, where different mtDNA regions have variable usefulness for the study of different problems. In particular, the results suggest that sequence length is not the relevant dimension to discuss the utility of the different data sets for the study of human population history in South America. We demonstrate that data sets with different sequence lengths display very similar distance matrices and almost identical phylogenetic trees (Table 1, Figures 2 and 3). The Control and Control-cyt $b$ data sets generated trees more similar to the Complete mtDNA data set tree. When we compare the distance matrices, we can observe that the Coding, Control, and Control-cytb data sets display a pattern of differences among cases similar to that of the Complete mtDNA data set. These results suggest that the control region has sufficient information to reconstruct the lineage 
genealogy or phylogeny of the mtDNA variants in South America. This result contrasts with the most general expectation that the length of sequence is important in experimental design (Goldman 1998). Conversely, the tree and distance matrix obtained with the HVRI data set display important differences with the other data sets. Therefore, we argue that this mtDNA region does not provide sufficient information to reconstruct a reliable phylogenetic tree and define the founding subhaplogroups that peopled South America, as has been previously suggested (Fagundes et al. 2008a; de Saint Pierre et al. 2012b).

However, the problem discussed here is not simple. As we point out above, previous studies also suggested that the high mutation and/or substitution rate of the noncoding HVRI and full control region could be a problem for the study of ancestral population dynamics in America, particularly because of the high frequency of recurrent mutations (Tamm et al. 2007; Fagundes et al. 2008b). Nevertheless, our results suggest that HVRI and the control region display a convenient rate of mutation for studying details of the Holocene demographic change in South America (Figures 4 and 5). In particular, when we analyze these molecular data sets, and when we explore the Control-cyt $b$ data set, the BSP analyses show a quick population increase ca. 7,000-6,000 years ago, which is similar to the results shown for South America by previous works employing molecular and archaeological data (Marquet et al. 2012; Goldberg et al. 2016; Perez et al. 2016). The results also show the impact of the European colonization during the last 500 years on the mtDNA molecular variation. Conversely, the Coding and Complete mtDNA data sets show less detail for the dynamics of population increase after ca. 7,000-6,000 years ago. The analyses of these data sets also suggest that this event was more recent, ca. 5,000 years ago, than the interpretation based on the BSP analysis of the noncoding sequences. Although this temporal difference in the time of the Holocene population increase could be related to uncertainties in the estimation of the substitution rate employed (Llamas et al. 2016), the BSP based on Coding and Complete mtDNA data sets shows another important difference: an additional population increase event ca. 19,000 years ago. This population increase has been described previously in DNA studies employing different data (Fagundes et al. 2008a, 2008b; Kitchen et al. 2008; Llamas et al. 2016; Poznik et al. 2016). However, it is important to remark that the estimated mean time of this event varies between 15,000 and 25,000 years ago, depending on the substitution rate employed by each study (Llamas et al. 2016).

All the results obtained in this work make sense if we consider the time scale of South American peopling and the values of sequence informativeness. The informativeness profiles show that only three data sets, Complete mtDNA, Control, and Control-cyt $b$, display relatively high values of net informativeness during the last 2,000 years (Figure 6). In particular, the Control and Control-cyt $b$ data sets display relatively high values of informativeness mainly in times close to the present, whereas the Complete mtDNA data displays high values in this period and during the initial divergence time ca. 17,000 years ago. The Coding data set also displays high values of informativeness for the earliest times analyzed. Both the Coding and Complete mtDNA data sets are very useful to study relatively ancient processes and events in America, but this large quantity of information about ancient events could cause problems in the estimation of more recent events, as suggested by our BSP results (Figure 5). These results, together with our other results, do not support the opinion that the mtDNA control region presents limited information for genealogical reconstruction and for the study of population history in America (Tamm et al. 2007; Fagundes et al. 2008a, 2008b). Conversely, the HVRI and the cyt $b-12 S-16 S$ data sets show low values of informativeness over time, corroborating its previously hypothesized limited value for the American human population studies. Our results also suggest that mtDNA regions widely used previously to explore phylogenetic relationships among closely related species or subspecies, such as cyt $b, 12 S$, and 16 S, do not display sufficient information to investigate the population processes in the time frame of South America human evolution, or in similar problems such as the peopling of the entire America, probably related to the fact that a relatively small number of mutations can be observed in this mtDNA region for our data set (Table 2, Figure 6).

In summary, we demonstrate the complex behavior of the different mtDNA data sets used in previous studies. They have different degrees 
of information to reconstruct phylogenetic trees with reliability and infer without error the founding monophyletic clades or subhaplogroups of America. Our results indicate that HVRI is not suitable for phylogenetic reconstruction of ancient clades because this mtDNA region does not have sufficient information of events that occurred in the distant past, that is, during the Pleistocene. Moreover, the HVRI and Control data sets display information for the demographic reconstruction during the Holocene period, where the high rate of mutation seems to be a valuable characteristic. Conversely, the Complete mtDNA, Coding, Control, and Control-cytb data sets display sufficient information for phylogenetic reconstruction in this geographic region during the time span of the human peopling. As expected, the complete mtDNA and coding region, displaying slower rates of mutation, present better information for the reconstruction of ancient demographic events.

\section{Final Remarks}

During the last decades it became obvious that inference of evolutionary patterns from molecular sequences is a statistical problem and requires the use of experimental design (Goldman 1998; Townsend 2007; Yang and Rannala 2012). Nevertheless, human population studies have paid little attention to this problem. Previous studies have followed the "empirical folklore" and a few worldscale studies (Non et al. 2007), such as occurred decades ago in the interspecies works (Goldman 1998), about the best molecular sequences to use and the sampling of individuals for population analyses. They have not systematically employed formal methods to explore the utility of different sequences or to sample individuals to test different population problems. Our results indicate the importance of evaluating the utility of different DNA regions to address different questions and problems in human population studies, mainly considering the time scale of the phenomenon and the informativeness of the molecular region in a particular geographical area.

In this study, we explored the utility of sequences for the reconstruction of human population history. However, the discussions about experimental design in molecular studies go beyond sequence informativeness (Goldman 1998; Graybeal 1998; Geuten et al. 2007). Therefore, future studies are needed to explore the impact of the use of multiple sequences and the sampling of individuals from different times and geographical areas in the reconstruction of human population history. This is particularly relevant if we consider that the mtDNA databases for regions such as HVRI or the control region are considerably larger than the sample of complete mtDNA genomes.

\section{ACKNOWLEDGMENTS}

We are sincerely grateful to Sergio Furtado dos Reis (UNICAMP, Brazil) for useful discussions about experimental design in phylogenetic studies. We also thank two anonymous reviewers for their comments that have greatly improved this article.

Received 17 July 2017; revision accepted for publication 5 February 2018.

\section{LITERATURE CITED}

Achilli, A., U. A. Perego, H. Lancioni et al. 2013. Reconciling migration models to the Americas with the variation of North American native mitogenomes. Proc. Natl. Acad. Sci. U. S. A. 110:14,308-14,313.

Andrews, R. M., I. Kubacka, P. F. Chinnery et al. 1999. Reanalysis and revision of the Cambridge reference sequence for human mitochondrial DNA. Nat. Genet. 23:147.

Bisso-Machado, R., M. C. Bortolini, and F. M. Salzano. 2012. Uniparental genetic markers in South Amerindians. Genet. Mol. Biol. 35:365-387.

Bodner, M., U. A. Perego, G. Huber et al. 2012. Rapid coastal spread of first Americans: Novel insights from South America's Southern Cone mitochondrial genomes. Genome Res. 22:811-820.

Camargo, A., L. J. Avila, M. Morando et al. 2012. Accuracy and precision of species trees: Effects of locus, individual, and base pair sampling on inference of species trees in lizards of the Liolaemus darwinii group (Squamata, Liolaemidae). Syst. Biol. 61:272-288.

Carnese, F. R., F. Mendisco, C. Keyser et al. 2010. Paleogenetical study of pre-Columbian samples from Pampa Grande (Salta, Argentina). Am. J. Phys. Anthropol. 141:452-462.

Cotton, J. A., and M. Wilkinson. 2008. Quantifying the potential utility of phylogenetic characters. Taxon 57:131-136 
Darriba, D., G. L. Taboada, R. Doallo et al. 2012. jModelTest 2: More models, new heuristics and parallel computing. Nat. Methods 9:772.

de Saint Pierre, M., C. M. Bravi, J. M. Motti et al. 2012a. An alternative model for the early peopling of southern South America revealed by analyses of three mitochondrial DNA haplogroups. PLoS One 7:e43486.

de Saint Pierre, M., F. Gandini, U. A. Perego et al. 2012b. Arrival of Paleo-Indians to the Southern Cone of South America: New clues from mitogenomes. PLoS One 7:e51311.

Dornburg, A., J. P. Townsend, M. Friedman et al. 2014. Phylogenetic informativeness reconciles ray-finned fish molecular divergence times. BMC Evol. Biol. 14:1.

Drummond, A. J., and A. Rambaut. 2007. BEAST: Bayesian evolutionary analysis by sampling trees. BMC Evol. Biol. 7:214.

Drummond, A. J., A. Rambaut, B. Shapiro et al. 2005. Bayesian coalescent inference of past population dynamics from molecular sequences. Mol. Biol. Evol. 22:1,185-1,192.

Endicott, P., and S. Y. W. Ho. 2008. A Bayesian evaluation of human mitochondrial substitution rates. Am. J. Hum. Genet. 82:895-902.

Fagundes, N. J., R. Kanitz, and S. L. Bonatto. 2008a. A reevaluation of the Native American mtDNA genome diversity and its bearing on the models of early colonization of Beringia. PLoS One 3:e3157.

Fagundes, N., R. Kanitz, R. Eckert et al. 2008b. Mitochondrial population genomics supports a single pre-Clovis origin with a coastal route for the peopling of the Americas. Am. J. Hum. Genet. 82:583-592.

Fehren-Schmitz, L. W. Haak, B. Mächtle et al. 2014. Climate change underlies global demographic, genetic, and cultural transitions in pre-Columbian southern Peru. Proc. Natl. Acad. Sci. U. S. A. 111:9,443-9,448.

Fehren-Schmitz, L., B. Llamas, E. Tomasto et al. 2011. El ADN antiguo y la historia del poblamiento temprano del Oeste de Sudamérica: Lo que hemos aprendido y hacia dónde vamos. Bol. Arqueol. PUCP 15:17-41.

Felsenstein, J. 2005. PHYLIP (Phylogeny Inference Package) version 3.6. Distributed by the author. Department of Genome Sciences, University of Washington, Seattle.

Geuten, K., T. Massingham, P. Darius et al. 2007. Experimental design criteria in phylogenetics: Where to add taxa. Syst. Biol. 56:609-622.

Goldberg, A., A. M. Mychajliw, and E. A. Hadly. 2016. Postinvasion demography of prehistoric humans in South America. Nature 532:232-235.

Goldman, N. 1998. Phylogenetic information and experimental design in molecular systematics. Proc. Biol. Sci. 265:1,779-1,786.

Graybeal, A. 1994. Evaluating the phylogenetic utility of genes: A search for genes informative about deep divergences among vertebrates. Syst. Biol. 43:174-193.

Graybeal, A. 1998. Is it better to add taxa or characters to a difficult phylogenetic problem? Syst. Biol. 47:9-17.

Guindon, S., and O. Gascuel. 2003. A simple, fast and accurate algorithm to estimate large phylogenies by maximum likelihood. Syst. Biol. 52:696-704.

Hall, T. 2004. BioEdit 7.0.0. http://www.mbio.ncsu.edu/ bioedit/bioedit.html.

Hammer, Ø., D. A. T. Harper, and P. D. Ryan. 2001. PAST: Paleontological statistics software package for education and data analysis. Palaeontol. Electron. 4:1-9.

Hartmann, A., M. Thieme, L. K. Nanduri et al. 2009. Validation of microarray-based resequencing of 93 worldwide mitochondrial genomes. Hum. Mutat. 30:115-122.

Ho, S. Y. W., and B. Shapiro. 2011. Skyline-plot methods for estimating demographic history from nucleotide sequences. Mol. Ecol. Resour. 11:423-434.

Just, R. S., T. M. Diegoli, J. L. Saunier. 2008. Complete mitochondrial genome sequences for 265 African American and US "Hispanic" individuals. Forensic Sci. Int. Genet. 2:e45-e48.

Katoh, K., and D. M. Standley. 2013. MAFFT multiple sequence alignment software version 7: Improvements in performance and usability. Mol. Biol. Evol. 30:772-780.

Kemp, B. M., and T. G. Schurr. 2010. Ancient and modern genetic variation in the Americas. In Human Variation in the Americas: The Integration of Archaeology and Biological Anthropology, B. M. Auerbach, ed. Carbondale: Southern Illinois University Board of Trustees, 12-50.

Kitchen, A., M. M. Miyamoto, and C. J. Mulligan. 2008. A three-stage colonization model for the peopling of the Americas. PLoS One 3:el596.

Kuhner, M. K., and J. Felsenstein. 1994. A simulation comparison of phylogeny algorithms under equal and unequal evolutionary rates. Mol. Biol. Evol. 11:459-468.

Kumar, S., G. Stecher, and K. Tamura 2016. MEGA7: Molecular Evolutionary Genetics Analysis version 7.0 for bigger datasets. Mol. Biol. Evol. 33:1,870-1,874.

Legendre, P., and L. Legendre. 1998. Numerical Ecology. Amsterdam: Elsevier.

Li, H., and Durbin, R. 2011. Inference of human population history from individual whole-genome sequences. Nature 475:493-496.

Llamas, B., L. Fehren-Schmitz, G. Valverde et al. 2016. Ancient mitochondrial DNA provides high-resolution time scale of the peopling of the Americas. Sci. Adv. 
2:e1501385

López-Giráldez, F., and J. P. Townsend. 2011. PhyDesign: An online application for profiling phylogenetic informativeness. BMC Evol. Biol. 11:1.

Lynch Alfaro, J. W., J. P. Boubli, L. E. Olson et al. 2012. Explosive Pleistocene range expansion leads to widespread Amazonian sympatry between robust and gracile capuchin monkeys. J. Biogeogr. 39:272-288.

Macaulay, V., C. Hill, A. Achilli et al. 2005. Single, rapid coastal settlement of Asia revealed by analysis of complete mitochondrial genomes. Science 308:1,034-1,036

Mallick, S., H. Li, M. Lipson et al. 2016. The Simons Genome Diversity Project: 300 genomes from 142 diverse populations. Nature 538:201-206.

Marín, J. C., A. E. Spotorno, B. A. González et al. 2008. Mitochondrial DNA variation and systematics of the guanaco (Lama guanicoe, Artiodactyla: Camelidae).J. Mammal. 89:269-281.

Marquet, P. A., C. M. Santoro, C. Latorre et al. 2012. Emergence of social complexity among coastal huntergatherers in the Atacama Desert of northern Chile. Proc. Natl. Acad. Sci. U. S. A. 109:14,754-14,760.

Mendisco, F., C. Keyser, V. Seldes et al. 2014. Genetic diversity of a late prehispanic group of the Quebrada de Humahuaca, northwestern Argentina. Ann. Hum. Genet. 78:367-380.

Metcalf, J. L., C. Turney, R. Barnett et al. 2016. Synergistic roles of climate warming and human occupation in Patagonian megafaunal extinctions during the last deglaciation. Sci. Adv. 2:e1501682.

Moraga, M., P. Rocco, J. F. Miquel et al. 2000. Mitochondrial DNA polymorphisms in Chilean aboriginal populations: Implications for the peopling of the Southern Cone of the continent. Am. J. Phys. Anthropol. 113:19-29.

Non, A. L., A. Kitchen, and C. J. Mulligan. 2007. Identification of the most informative regions of the mitochondria genome for phylogenetic and coalescent analyses. $\mathrm{Mol}$. Phylogenet. Evol. 44:1,164-1,171.

O'Rourke, D. H., and J. A. Raff. 2010. The human genetic history of the Americas: The final frontier. Curr. Biol. 20:R202-R207.

Perego, U. A., A. Achilli, N. Angerhofer et al. 2009. Distinctive Paleo-Indian migration routes from Beringia marked by two rare mtDNA haplogroups. Curr. Biol. 19:1-8.

Perego, U. A., N. Angerhofer, M. Pala et al. 2010. The initial peopling of the Americas: A growing number of founding mitochondrial genomes from Beringia. Genome Res. 20:1,174-1,179.

Perez, S. I., M. B. Postillone, D. Rindel et al. 2016. Peopling time, spatial occupation and demography of late
Pleistocene-Holocene human population from Patagonia. Quat. Int. 425:214-223.

Postillone, M. B., M. L. Fuchs, C. M. Crespo et al. 2017. Linajes maternos en muestras antiguas de la Puna Jujeña: Comparación con estudios de la región Centro-Sur Andina. Rev. Argent. Antropol. Biol. 19:7-22.

Poznik, G. D., Y. Xue, F. L. Mendez et al. 2016. Punctuated bursts in human male demography inferred from 1,244 worldwide Y-chromosome sequences. Nat. Genet. 48:593-599.

Rambaut, A., and A. J. Drummond. 2007. Tracer v1.5. http:// tree.bio.ed.ac.uk/software/tracer/.

Rasmussen, M., X. Guo, Y. Wang et al. 2011. An Aboriginal Australian genome reveals separate human dispersals into Asia. Science 334:94-98.

Robinson, D. F., and L. R. Foulds. 1981. Comparison of phylogenetic trees. Math. Biosci. 53:131-147.

Rozas, J. 2009. DNA sequence polymorphism analysis using DnaSP. In Bioinformatics for DNA Sequence Analysis: Methods in Molecular Biology Series, Vol. 537, D. Posada, ed. New York: Humana Press, 337-350.

Rubicz, R. C., P. E. Melton, and M. H. Crawford. 2007. Molecular markers in anthropological genetic studies. In Anthropological Genetics: Theory, Methods and Applications, M. H. Crawford, ed. Cambridge: Cambridge University Press, 141-186.

Smouse, P. E., J. C. Long, and R. R. Sokal. 1986. Multiple regression and correlation extensions of the Mantel test of matrix correspondence. Syst. Zool. 35:627-632.

Soares, P., L. Ermini, N. Thomson et al. 2009. Correcting for purifying selection: An improved human mitochondrial molecular clock. Am. J. Hum. Genet. 84:740-759.

Tamm, E., T. Kivisild, M. Reidla et al. 2007. Beringian standstill and spread of Native American founders. PLoS One 2:829.

Tamura, K., M. Nei, and S. Kumar. 2004. Prospects for inferring very large phylogenies by using the neighbor-joining method. Proc. Natl. Acad. Sci. U. S. A 101:11,030-11,035.

Townsend, J. P. 2007. Profiling phylogenetic informativeness. Syst. Biol. 56:222-231.

Vigilant, L., M. Stoneking, H. Harpending et al. 1991. African populations and the evolution of human mitochondrial DNA. Science 253:1,503-1,507.

Wallace, D. C. 2015. Mitochondrial DNA variation in human radiation and disease. Cell 163:33-38.

Yang, Z. 1998. On the best evolutionary rate for phylogenetic analysis. Syst. Biol. 47:125-133.

Yang, Z., and B. Rannala. 2012. Molecular phylogenetics: Principles and practice. Nat. Rev. Genet. 13:303-314. 

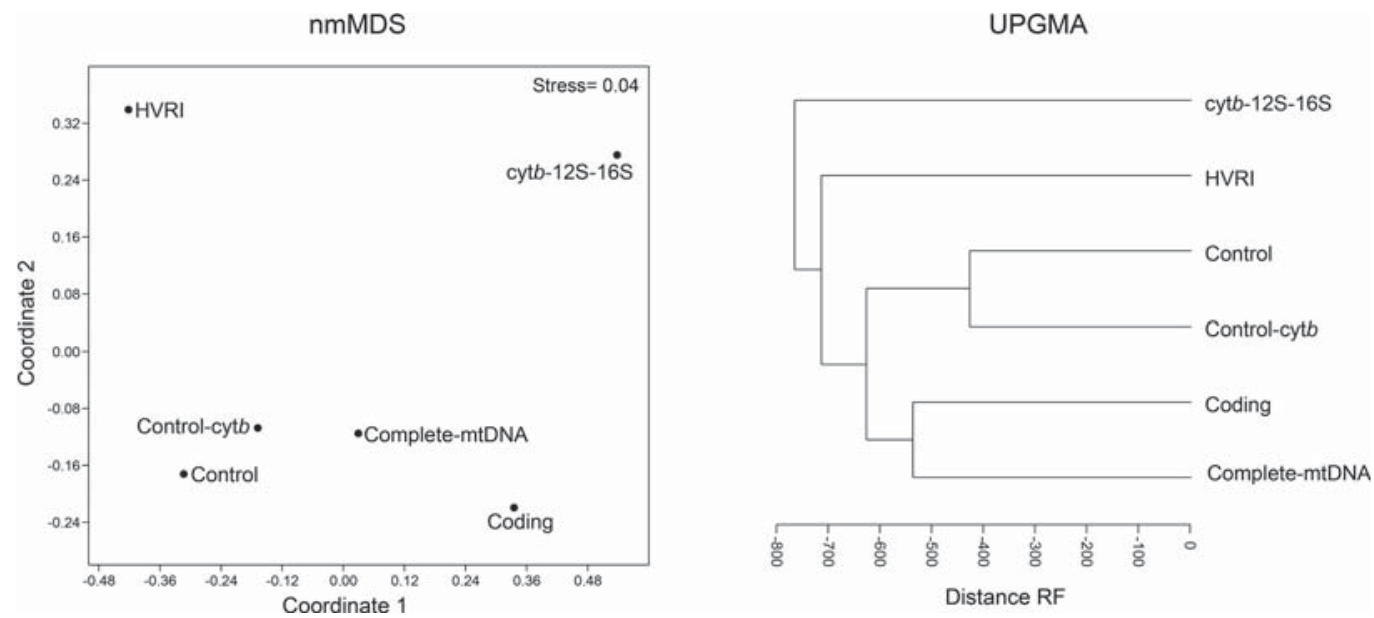

SUPPLEMENTARY FIGURE S1. Nonmetric multidimensional scaling (nmMDS) and unweighted pair group method with arithmetic mean (UPGMA) cluster analyses of topological differences among the phylogenetic trees for all American sequences. The analyses used the Robinson-Foulds (RF) distance to estimate the similarity between the data sets.
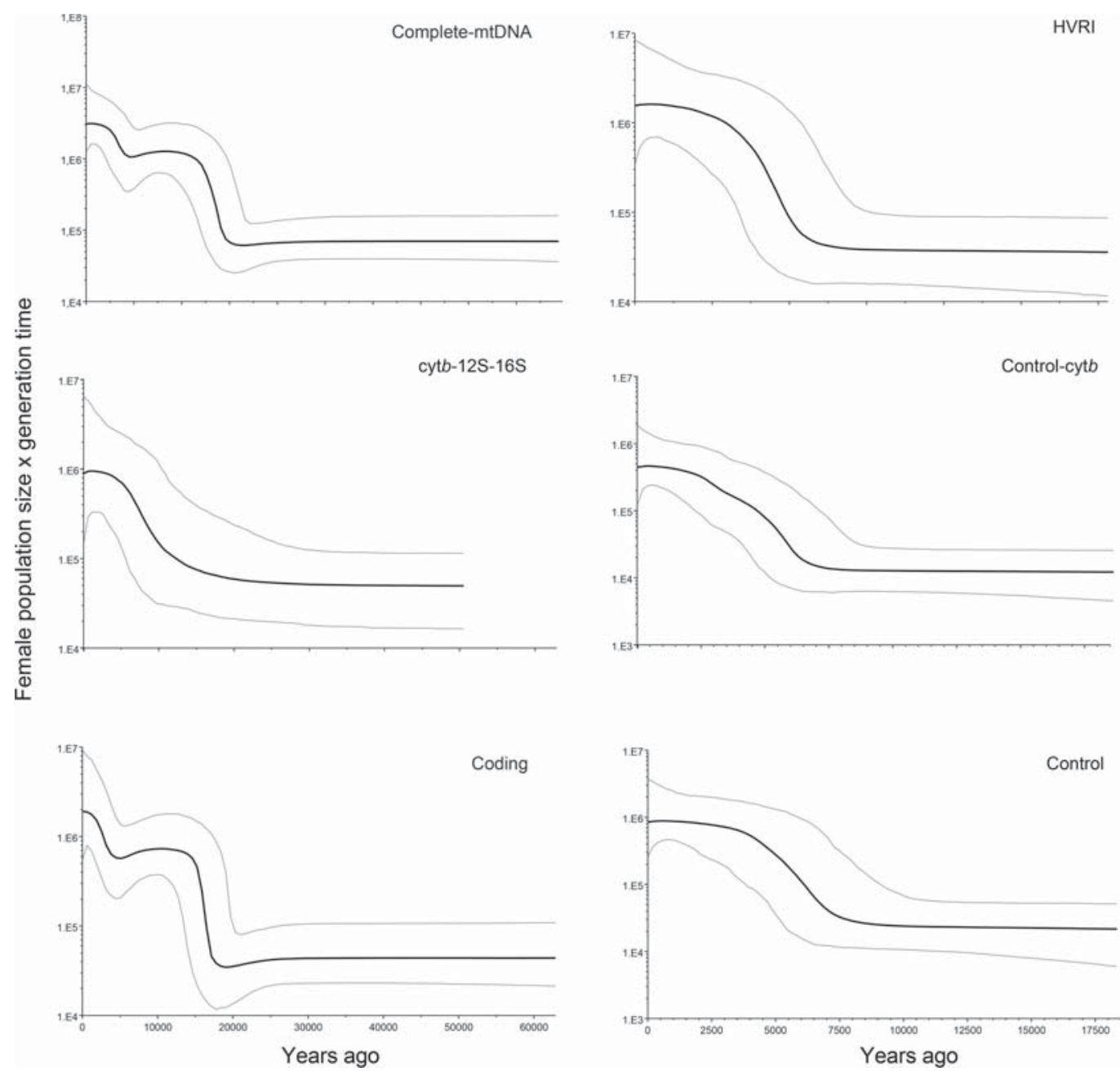

SUPPLEMENTARY FIGURE S2. Demographic changes in South America estimated based on the modern molecular sequences of the six data sets studied. The times are scaled. 
Supplementary Table S1. Data Set of 259 Complete Mitochondrial DNA (mtDNA) Sequences from Modern and Ancient Humans of South America (South-Central Andes, $n=123$; Northeast, $n=17$; Pampa-Patagonia, $n=119$ ) Used in This Study

\begin{tabular}{|c|c|c|c|c|}
\hline Genebank Accession \# & This Study ID & Haplogroup/Haplotype & Geographic Region & Paper \\
\hline JN253392.1 & 1.D1 & D1 & Argentina, Río Negro & Bodner et al. 2012 \\
\hline JN253393.1 & 2.D1g & D1g & Chile, Los Lagos & Bodner et al. 2012 \\
\hline JN253394.1 & 3.Dlgla & D1gla & Argentina, Buenos Aires & Bodner et al. 2012 \\
\hline JN253395.1 & 4.Dlgla & D1gla & Argentina, Río Negro & Bodner et al. 2012 \\
\hline JN253396.1 & 5.Dlgla & D1gla & Argentina, Río Negro & Bodner et al. 2012 \\
\hline JN253397.1 & 6.D1gla & D1gla & Argentina, Río Negro & Bodner et al. 2012 \\
\hline JN253398.1 & 7.D1g1b & D1g1b & Chile, Tarapacá & Bodner et al. 2012 \\
\hline JN253399.1 & 8.D1g1b & D1g1b & Argentina, Chubut & Bodner et al. 2012 \\
\hline JN253400.1 & 9.D1g1b & $\mathrm{D} 1 \mathrm{~g} 1 \mathrm{~b}$ & Argentina, Río Negro & Bodner et al. 2012 \\
\hline JN253401.1 & 10.D1g2 & D1g2 & Chile, Biobio & Bodner et al. 2012 \\
\hline JN253402.1 & 11.D1g2 & D1g2 & Argentina, Buenos Aires & Bodner et al. 2012 \\
\hline JN253403.1 & 12.D1g2 & D1g2 & Argentina, Río Negro & Bodner et al. 2012 \\
\hline JN253404.1 & 13.D1g2a & D1g2a & Argentina, Río Negro & Bodner et al. 2012 \\
\hline JN253405.1 & 14.D1g2a & D1g2a & Argentina, Río Negro & Bodner et al. 2012 \\
\hline JN253406.1 & 15.D1g2a & D1g2a & Argentina, Río Negro & Bodner et al. 2012 \\
\hline JN253407.1 & 16.D1g3 & D1g3 & Chile, Maule & Bodner et al. 2012 \\
\hline JN253408.1 & 17.D1g3 & Dlg3 & Chile, Valparaíso & Bodner et al. 2012 \\
\hline JN253409.1 & 18.D1g3 & Dlg3 & Argentina, Río Negro & Bodner et al. 2012 \\
\hline JN253410.1 & 19.D1g4a & D1g4a & Chile, Valparaíso & Bodner et al. 2012 \\
\hline JN253411.1 & 20.D1g4a & D1g4a & Argentina, Río Negro & Bodner et al. 2012 \\
\hline JN253412.1 & 21.D1g4 & D1g4 & Chile, Atacama & Bodner et al. 2012 \\
\hline JN253413.1 & 22.D1g5 & D1g5 & Chile, Aisen & Bodner et al. 2012 \\
\hline JN253414.1 & 23.D1g5 & D1g5 & Argentina, Buenos Aires & Bodner et al. 2012 \\
\hline JN253415.1 & 24.D1g5 & D1g5 & Argentina, Río Negro & Bodner et al. 2012 \\
\hline JN253416.1 & 25.D1g5 & D1g5 & Argentina, Río Negro & Bodner et al. 2012 \\
\hline JN253417.1 & 26.D1g6 & D1g6 & Chile, Araucania & Bodner et al. 2012 \\
\hline JN253418.1 & 27.D1g6 & D1g6 & Argentina, Neuquén & Bodner et al. 2012 \\
\hline JN253419.1 & 28.D1j & D1j & Chile, Biobio & Bodner et al. 2012 \\
\hline JN253420.1 & 29.D1j & $\mathrm{D} 1 \mathrm{j}$ & Brazil, Río Grande do Sul & Bodner et al. 2012 \\
\hline JN253421.1 & 30.D1j1 & D1j1 & Argentina, Buenos Aires & Bodner et al. 2012 \\
\hline JN253422.1 & 31.D1j1 & D1j1 & Argentina, Catamarca & Bodner et al. 2012 \\
\hline JN253423.1 & 32.D1j1a & D1j1a & Argentina, Córdoba & Bodner et al. 2012 \\
\hline JN253424.1 & 33.D1j1a & D1j1a & Chile, Maule & Bodner et al. 2012 \\
\hline JN253425.1 & 34.D1j1a & D1j1a & Chile, Valparaíso & Bodner et al. 2012 \\
\hline JN253426.1 & 35.D1j1a & D1j1a & Brazil, São Paulo & Bodner et al. 2012 \\
\hline JN253427.1 & 36.D1j1a & D1j1a & Argentina, Catamarca & Bodner et al. 2012 \\
\hline JN253428.1 & 37.D1j1a & D1j1a & Argentina, Catamarca & Bodner et al. 2012 \\
\hline JN253429.1 & 38.D1j1a1 & D1jla1 & Argentina, Tucumán & Bodner et al. 2012 \\
\hline JN253430.1 & 39.D1j1a1 & D1j1a1 & Argentina, Buenos Aires & Bodner et al. 2012 \\
\hline JN253431.1 & 40.D1j1a1 & D1j1a1 & Argentina, Buenos Aires & Bodner et al. 2012 \\
\hline JN253432.1 & 41.D1j1a1 & D1j1a1 & Argentina, Buenos Aires & Bodner et al. 2012 \\
\hline JN253433.1 & 42.D1j1a1 & D1j1a1 & Argentina, Salta & Bodner et al. 2012 \\
\hline JN253434.1 & 43.D1j1a2 & D1j1a2 & Argentina, Buenos Aires & Bodner et al. 2012 \\
\hline JN253435.1 & 44.D1j1a2 & D1j1a2 & Argentina, Corrientes & Bodner et al. 2012 \\
\hline JN253391.1 & 45.D1 & D1 & Argentina, Buenos Aires & Bodner et al. 2012 \\
\hline JX413011.1 & 46.B2i2a & B2i2a & Argentina, Río Negro & de Saint Pierre et al. 2012 \\
\hline JX413012.1 & 47.B2i2a & $\mathrm{B} 2 \mathrm{i} 2 \mathrm{a}$ & Argentina, Neuquén & de Saint Pierre et al. 2012 \\
\hline JX413013.1 & 48.B2i2a & $\mathrm{B} 2 \mathrm{i} 2 \mathrm{a}$ & Argentina, Neuquén & de Saint Pierre et al. 2012 \\
\hline JX413014.1 & 49.B2i2a & $\mathrm{B} 2 \mathrm{i} 2 \mathrm{a}$ & Chile, Isla de Chiloé & de Saint Pierre et al. 2012 \\
\hline$J X 413015.1$ & $50 . B 2 i 2 a$ & $\mathrm{~B} 2 \mathrm{i} 2 \mathrm{a}$ & Chile, Isla de Chiloé & de Saint Pierre et al. 2012 \\
\hline
\end{tabular}




\begin{tabular}{|c|c|c|c|c|}
\hline Genebank Accession \# & This Study ID & Haplogroup/Haplotype & Geographic Region & Paper \\
\hline$J X 413016.1$ & 51.B2i2a & B2i2a & Chile, Isla de Chiloé & de Saint Pierre et al. 2012 \\
\hline$J X 413017.1$ & 52.B2i2a & B2i2a & Chile, Aconcagua & de Saint Pierre et al. 2012 \\
\hline$J X 413018.1$ & 53.B2i2a & B2i2a & Chile & de Saint Pierre et al. 2012 \\
\hline$J X 413019.1$ & 54.B2i2a & B2i2a & Argentina, Río Negro & de Saint Pierre et al. 2012 \\
\hline$J X 413020.1$ & 55.B2i2a & B2i2a & Chile & de Saint Pierre et al. 2012 \\
\hline$J X 413021.1$ & 56.B2i2a & B2i2a & Chile, Aconcagua & de Saint Pierre et al. 2012 \\
\hline$J X 413022.1$ & 57.B2i2a & B2i2a & Chile & de Saint Pierre et al. 2012 \\
\hline$J X 413023.1$ & 58.B2i2a & B2i2a & Chile, Aconcagua & de Saint Pierre et al. 2012 \\
\hline$J X 413024.1$ & 59.B2i2b & B2i2b & Chile, Aconcagua & de Saint Pierre et al. 2012 \\
\hline$J X 413025.1$ & $60 . \mathrm{B} 2 \mathrm{i} 2 \mathrm{~b}$ & $\mathrm{~B} 2 \mathrm{i} 2 \mathrm{~b}$ & Chile, Aconcagua & de Saint Pierre et al. 2012 \\
\hline$J X 413026.1$ & 61.B2i2b & $\mathrm{B} 2 \mathrm{i} 2 \mathrm{~b}$ & Chile, Isla de Chiloé & de Saint Pierre et al. 2012 \\
\hline$J X 413027.1$ & 62.B2i2b & $\mathrm{B} 2 \mathrm{i} 2 \mathrm{~b}$ & Chile, Valparaíso & de Saint Pierre et al. 2012 \\
\hline$J X 413028.1$ & 63.B2i2b & $\mathrm{B} 2 \mathrm{i} 2 \mathrm{~b}$ & Chile & de Saint Pierre et al. 2012 \\
\hline$J X 413029.1$ & 64.B2i2b & $\mathrm{B} 2 \mathrm{i} 2 \mathrm{~b}$ & Chile, Aconcagua & de Saint Pierre et al. 2012 \\
\hline$J X 413030.1$ & 65.B2i2b & $\mathrm{B} 2 \mathrm{i} 2 \mathrm{~b}$ & Chile, Isla de Chiloé & de Saint Pierre et al. 2012 \\
\hline$J X 413031.1$ & 66.B2i2b & $\mathrm{B} 2 \mathrm{i} 2 \mathrm{~b}$ & Argentina, Río Negro & de Saint Pierre et al. 2012 \\
\hline$J X 413032.1$ & 67.B2i2b & $\mathrm{B} 2 \mathrm{i} 2 \mathrm{~b}$ & Chile, Aconcagua & de Saint Pierre et al. 2012 \\
\hline$J X 413033.1$ & 68.B2i2b & $\mathrm{B} 2 \mathrm{i} 2 \mathrm{~b}$ & Chile, Aconcagua & de Saint Pierre et al. 2012 \\
\hline$J X 413034.1$ & 69.B2i2b & $\mathrm{B} 2 \mathrm{i} 2 \mathrm{~b}$ & Chile, San Juan de la Costa & de Saint Pierre et al. 2012 \\
\hline$J X 413035.1$ & 70.B2i2 & $\mathrm{B} 2 \mathrm{i} 2$ & Chile, Santiago & de Saint Pierre et al. 2012 \\
\hline$J X 413036.1$ & 71.C1b13a & C1b13a & Chile, San Juan de la Costa & de Saint Pierre et al. 2012 \\
\hline$J X 413037.1$ & 72.C1b13a & C1b13a & Chile, Aconcagua & de Saint Pierre et al. 2012 \\
\hline$J X 413038.1$ & 73.C1b13a & C1b13a & Chile, Aconcagua & de Saint Pierre et al. 2012 \\
\hline$J X 413039.1$ & 74.C1b13a & C1b13a & Chile & de Saint Pierre et al. 2012 \\
\hline$J X 413040.1$ & 75.C1b13a & C1b13a & Chile, Aconcagua & de Saint Pierre et al. 2012 \\
\hline$J X 413041.1$ & 76.C1b13b & C1b13b & Chile, San Juan de la Costa & de Saint Pierre et al. 2012 \\
\hline$J X 413042.1$ & 77.C1b13b & C1b13b & Chile, isla de Chiloé & de Saint Pierre et al. 2012 \\
\hline$J X 413043.1$ & $78 . \mathrm{C} 1 \mathrm{~b} 13 \mathrm{~b}$ & C1b13b & Chile, Talagante & de Saint Pierre et al. 2012 \\
\hline JX413044.1 & 79.C1b13c & C1b13c & Argentina, Neuquén & de Saint Pierre et al. 2012 \\
\hline$J X 413045.1$ & $80 . C 1 b 13 c$ & C1b13c & Chile, Isla de Chiloé & de Saint Pierre et al. 2012 \\
\hline$J X 413046.1$ & $81 . C 1 b 13 c$ & C1b13c & Chile & de Saint Pierre et al. 2012 \\
\hline$J X 413047.1$ & $82 . C 1 b 13 c$ & C1b13c & Chile & de Saint Pierre et al. 2012 \\
\hline$J X 413048.1$ & $83 . C 1 b 13 c$ & C1b13c & Chile, Trapa Trapa & de Saint Pierre et al. 2012 \\
\hline$J X 413049.1$ & 84.C1b13d & C1b13d & Chile, Aconcagua & de Saint Pierre et al. 2012 \\
\hline$J X 413050.1$ & $85 . C 1 b 13 d$ & C1b13d & Chile & de Saint Pierre et al. 2012 \\
\hline JX413051.1 & $86 . C 1 b 13 e$ & C1b13e & Chile, isla de Chiloé & de Saint Pierre et al. 2012 \\
\hline$J X 413052.1$ & $87 . C 1 b 13 e$ & C1b13e & Chile & de Saint Pierre et al. 2012 \\
\hline$J X 413053.1$ & $88 . C 1 b 13 e$ & C1b13e & Chile, isla de Chiloé & de Saint Pierre et al. 2012 \\
\hline JX413054.1 & $89 . C 1 b 13 e$ & C1b13e & Chile, Aconcagua & de Saint Pierre et al. 2012 \\
\hline$J X 413055.1$ & $90 . \mathrm{C} 1 \mathrm{~b} 13$ & C1b13 & Argentina, Salta & de Saint Pierre et al. 2012 \\
\hline$J X 413056.1$ & 91.C1b13 & C1b13 & Chile, Isla de Chiloé & de Saint Pierre et al. 2012 \\
\hline EU597486.1 & 92.A2 & $\mathrm{A} 2$ & Colombia & Hartmann et al. 2009 \\
\hline EU597498.1 & 93.D1 & D1 & Brazil, Karitiana & Hartmann et al. 2009 \\
\hline EU597510.1 & 94.D1 & D1 & Brazil, Karitiana & Hartmann et al. 2009 \\
\hline EU597534.1 & 95.B2 & B2 & Andes & Hartmann et al. 2009 \\
\hline EU597546.1 & 96.D4h & D4h & Brazil, Guyana, Venezuela & Hartmann et al. 2009 \\
\hline EU597569.1 & 97.B2 & B2 & Colombia & Hartmann et al. 2009 \\
\hline EU597580.1 & 98.B2 & B2 & Colombia & Hartmann et al. 2009 \\
\hline FJ168713.1 & 99.D4h3a1 & D4h3a1 & Chile, Atacama & Perego et al. 2009 \\
\hline FJ168714.1 & 100.D4h3a1 & D4h3a1 & Chile, Coquimbo & Perego et al. 2009 \\
\hline FJ168715.1 & 101.D4h3a1 & D4h3a1 & Chile, O'Higgins & Perego et al. 2009 \\
\hline FJ168716.1 & 102.D4h3a1 & D4h3a1 & Chile, Biobio & Perego et al. 2009 \\
\hline FJ168717.1 & 103.D4h3a1 & D4h3a1 & Chile, Biobio & Perego et al. 2009 \\
\hline FJ168718.1 & 104.D4h3a1 & D4h3a1 & Chile, Coquimbo & Perego et al. 2009 \\
\hline
\end{tabular}




\begin{tabular}{|c|c|c|c|c|}
\hline Genebank Accession \# & This Study ID & Haplogroup/Haplotype & Geographic Region & Paper \\
\hline FJ168719.1 & 105.D4h3a1 & D4h3a1 & Chile, Talcahuano & Perego et al. 2009 \\
\hline FJ168720.1 & 106.D4h3a1 & D4h3a1 & Chile, Santiago & Perego et al. 2009 \\
\hline FJ168721.1 & 107.D4h3a1 & D4h3a1 & Chile, Los Lagos & Perego et al. 2009 \\
\hline FJ168722.1 & 108.D4h3a1 & D4h3a1 & Chile, Biobio & Perego et al. 2009 \\
\hline FJ168723.1 & 109.D4h3a1 & D4h3a1 & Chile, Biobio & Perego et al. 2009 \\
\hline FJ168724.1 & 110.D4h3a2 & D4h3a2 & Chile, Biobio & Perego et al. 2009 \\
\hline FJ168725.1 & 111.D4h3a2 & D4h3a2 & Chile, Biobio & Perego et al. 2009 \\
\hline FJ168726.1 & 112.D4h3a2 & D4h3a2 & Chile, Coquimbo & Perego et al. 2009 \\
\hline FJ168727.1 & 113.D4h3a2 & D4h3a2 & Chile, Biobio & Perego et al. 2009 \\
\hline FJ168728.1 & 114.D4h3a3 & D4h3a3 & Chile, Tarapacá & Perego et al. 2009 \\
\hline FJ168735.1 & 115.D4h3a4 & D4h3a4 & Perú, Suyu & Perego et al. 2009 \\
\hline FJ168736.1 & 116.D4h3a4 & D4h3a4 & Perú, Arequipa & Perego et al. 2009 \\
\hline FJ168737.1 & 117.D4h3a4 & D4h3a4 & Perú, Arequipa & Perego et al. 2009 \\
\hline FJ168738.1 & 118.D4h3a5 & D4h3a5 & Perú, La Libertad & Perego et al. 2009 \\
\hline FJ168739.1 & 119.D4h3a5 & D4h3a5 & Chile, Maule & Perego et al. 2009 \\
\hline FJ168740.1 & 120.D4h3a5 & D4h3a5 & Chile, Los Lagos & Perego et al. 2009 \\
\hline FJ168741.1 & 121.D4h3a5 & D4h3a5 & Chile, Santiago & Perego et al. 2009 \\
\hline FJ168743.1 & 122.D4h3a3 & D4h3a3 & Perú, Arequipa & Perego et al. 2009 \\
\hline FJ168744.1 & 123.D4h3a & D4h3a & Perú, Arequipa & Perego et al. 2009 \\
\hline FJ168747.1 & 124.D4h3a & D4h3a & Perú, Loreto & Perego et al. 2009 \\
\hline FJ168748.1 & 125.D4h3a & D4h3a & Perú, Loreto & Perego et al. 2009 \\
\hline FJ168749.1 & 126.D4h3a & D4h3a & Perú, Piura & Perego et al. 2009 \\
\hline FJ168750.1 & 127.D4h3a & D4h3a & Bolivia, La Paz & Perego et al. 2009 \\
\hline FJ168751.1 & 128.D4h3a & D4h3a & Perú, Apurimac & Perego et al. 2009 \\
\hline FJ168752.1 & 129.D4h3a & D4h3a & Perú, Ancash & Perego et al. 2009 \\
\hline FJ168754.1 & 130.D4h3a & D4h3a & Brazil, Maranhâo & Perego et al. 2009 \\
\hline HM107309.1 & 131.C1d & C1d & Argentina, Salta & Perego et al. 2010 \\
\hline HM107310.1 & 132.C1d & C1d & Argentina, Salta & Perego et al. 2010 \\
\hline HM107311.1 & 133.C1d2a & C1d2a & Colombia & Perego et al. 2010 \\
\hline HM107312.1 & 134.C1d2a & $\mathrm{C} 1 \mathrm{~d} 2 \mathrm{a}$ & Colombia & Perego et al. 2010 \\
\hline HM107313.1 & 135.C1d2a & C1d2a & Colombia & Perego et al. 2010 \\
\hline HM107314.1 & 136.C1d2a & $\mathrm{C} 1 \mathrm{~d} 2 \mathrm{a}$ & Colombia & Perego et al. 2010 \\
\hline HM107315.1 & 137.C1d2 & $\mathrm{C} 1 \mathrm{~d} 2$ & Colombia & Perego et al. 2010 \\
\hline HM107316.1 & 138.C1d & Cld & Argentina, Buenos Aires & Perego et al. 2010 \\
\hline HM107317.1 & 139.C1d & C1d & Colombia & Perego et al. 2010 \\
\hline HM107323.1 & $140 . \mathrm{Cld} 1 \mathrm{~b}$ & $\mathrm{C} 1 \mathrm{~d} 1 \mathrm{~b}$ & Argentina, Salta & Perego et al. 2010 \\
\hline HM107324.1 & 141.C1d1b & C1d1b & Argentina, Catamarca & Perego et al. 2010 \\
\hline HM107325.1 & 142.C1d1b & C1d1b & Argentina, Salta & Perego et al. 2010 \\
\hline HM107326.1 & 143.C1d1b1 & C1d1b1 & Argentina, Catamarca & Perego et al. 2010 \\
\hline HM107327.1 & 144.C1d1b1 & C1d1b1 & Argentina, Buenos Aires & Perego et al. 2010 \\
\hline HM107328.1 & 145.C1d1b1 & C1d1b1 & Argentina, Río Negro & Perego et al. 2010 \\
\hline HM107329.1 & 146.C1d1b1 & C1d1b1 & Argentina, Buenos Aires & Perego et al. 2010 \\
\hline HM107330.1 & 147.C1d1b1 & C1d1b1 & Argentina, Corrientes & Perego et al. 2010 \\
\hline HM107331.1 & 148.C1d1b1 & C1d1b1 & Uruguay, Flores & Perego et al. 2010 \\
\hline HM107332.1 & 149.C1d1b1 & C1d1b1 & Argentina, Buenos Aires & Perego et al. 2010 \\
\hline HM107333.1 & 150.C1d1b1 & C1d1b1 & Argentina, Salta & Perego et al. 2010 \\
\hline HM107338.1 & 151.C1d1 & C1d1 & Brazil, Río Grande do Sul & Perego et al. 2010 \\
\hline HM107339.1 & 152.C1d1 & C1d1 & Perú, Lima & Perego et al. 2010 \\
\hline HM107340.1 & 153.C1d1 & C1d1 & Argentina, Buenos Aires & Perego et al. 2010 \\
\hline HM107341.1 & 154.C1d1 & C1d1 & Perú, Loreto & Perego et al. 2010 \\
\hline HM107342.1 & 155.C1d1 & C1d1 & Perú, Loreto & Perego et al. 2010 \\
\hline HM107343.1 & 156.C1d1 & C1d1 & Ecuador, Imbabura & Perego et al. 2010 \\
\hline HM107344.1 & 157.C1d1 & C1d1 & Colombia & Perego et al. 2010 \\
\hline HM107345.1 & 158.C1d1 & C1d1 & Colombia & Perego et al. 2010 \\
\hline
\end{tabular}




\begin{tabular}{|c|c|c|c|c|}
\hline Genebank Accession \# & This Study ID & Haplogroup/Haplotype & Geographic Region & Paper \\
\hline HM107346.1 & 159.C1d1d & Cld1d & Argentina, Buenos Aires & Perego et al. 2010 \\
\hline HM107347.1 & 160.C1d1d & Cld1d & Brazil, Río Grande do Sul & Perego et al. 2010 \\
\hline HM107348.1 & 161.C1d1d & Cld1d & Uruguay & Perego et al. 2010 \\
\hline HM107349.1 & 162.C1d1 & C1d1 & Brazil, Minas Gerais & Perego et al. 2010 \\
\hline HM107350.1 & 163.C1d1e & C1d1e & Chile, Biobio & Perego et al. 2010 \\
\hline HM107351.1 & 164.C1d1e & Cldle & Argentina, Río Negro & Perego et al. 2010 \\
\hline HM107352.1 & 165.C1d1 & C1d1 & Perú, Cajamarca & Perego et al. 2010 \\
\hline HM107353.1 & 166.C1d1 & C1d1 & Perú, Huanucu & Perego et al. 2010 \\
\hline HM107354.1 & 167.C1d1 & C1d1 & Perú, Puca Puca & Perego et al. 2010 \\
\hline HM107355.1 & 168.C1d1 & C1d1 & Argentina, Buenos Aires & Perego et al. 2010 \\
\hline HM107356.1 & 169.C1d1 & C1d1 & Brazil, Mato grosso do Sul & Perego et al. 2010 \\
\hline HM107357.1 & 170.C1d1 & C1d1 & Paraguay & Perego et al. 2010 \\
\hline HM107358.1 & 171.C1d1 & C1d1 & Argentina, Salta & Perego et al. 2010 \\
\hline HM107359.1 & 172.C1d1 & C1d1 & Perú, Piura & Perego et al. 2010 \\
\hline HM107360.1 & 173.C1d1 & C1d1 & Perú, Huancavelica & Perego et al. 2010 \\
\hline HM107361.1 & 174.C1d1 & C1d1 & Argentina, Corrientes & Perego et al. 2010 \\
\hline HM107362.1 & 175.C1d1 & C1d1 & Chile, Los Lagos & Perego et al. 2010 \\
\hline HM107363.1 & 176.C1d1 & Cld1 & Chile, Los Lagos & Perego et al. 2010 \\
\hline EU095222.1 & 177.C1d1 & C1d1 & Brazil & Perego et al. 2010 \\
\hline KU523264.1 & 178.A2 & $\mathrm{A} 2$ & Perú, Wari & Llamas et al. 2016 \\
\hline KU523265.1 & 179.A2 & $\mathrm{A} 2$ & Perú, Wari & Llamas et al. 2016 \\
\hline KU523266.1 & 180.A2 & A2 & Perú, Lima & Llamas et al. 2016 \\
\hline KU523267.1 & 181.A2 & $\mathrm{A} 2$ & Perú & Llamas et al. 2016 \\
\hline KU523268.1 & 182.A2 & A2 & Perú, Tiwanaku & Llamas et al. 2016 \\
\hline KU523269.1 & 183.A2 & $\mathrm{A} 2$ & Argentina, Arroyo Seco & Llamas et al. 2016 \\
\hline KU523270.1 & 184.A2 & $\mathrm{A} 2$ & Chile & Llamas et al. 2016 \\
\hline KU523271.1 & 185.A2 & A2 & Perú & Llamas et al. 2016 \\
\hline KU523272.1 & 186.A2 & $\mathrm{A} 2$ & Chile & Llamas et al. 2016 \\
\hline KU523273.1 & 187.A2 & $\mathrm{A} 2$ & Chile & Llamas et al. 2016 \\
\hline KU523274.1 & 188.A2 & $\mathrm{A} 2$ & Perú & Llamas et al. 2016 \\
\hline KU523275.1 & 189.B2b & $\mathrm{B} 2 \mathrm{~b}$ & Perú & Llamas et al. 2016 \\
\hline KU523276.1 & 190.B2 & B2 & Perú & Llamas et al. 2016 \\
\hline KU523277.1 & 191.B2b & B2b & Perú & Llamas et al. 2016 \\
\hline KU523278.1 & 192.B2b & $\mathrm{B} 2 \mathrm{~b}$ & Perú & Llamas et al. 2016 \\
\hline KU523279.1 & 193.B2 & B2 & Perú & Llamas et al. 2016 \\
\hline KU523280.1 & 194.B2b & B2b & Perú, Wari & Llamas et al. 2016 \\
\hline KU523281.1 & 195.B2b & B2b & Perú, Wari & Llamas et al. 2016 \\
\hline KU523282.1 & 196.B2b & $\mathrm{B} 2 \mathrm{~b}$ & Perú, Wari & Llamas et al. 2016 \\
\hline KU523283.1 & 197.B2b & $\mathrm{B} 2 \mathrm{~b}$ & Perú, Lima & Llamas et al. 2016 \\
\hline KU523284.1 & 198.B2 & B2 & Perú & Llamas et al. 2016 \\
\hline KU523285.1 & 199.B2b & B2b & Perú & Llamas et al. 2016 \\
\hline KU523286.1 & $200 . B 2$ & B2 & Perú, Lima & Llamas et al. 2016 \\
\hline KU523287.1 & 201.B2 & B2 & Perú, Lima & Llamas et al. 2016 \\
\hline KU523288.1 & 202.B2 & B2 & Perú, Lima & Llamas et al. 2016 \\
\hline KU523289.1 & 203.B2 & B2 & Chile & Llamas et al. 2016 \\
\hline KU523290.1 & 204.B2 & B2 & Chile & Llamas et al. 2016 \\
\hline KU523291.1 & $205 . B 2$ & B2 & Chile & Llamas et al. 2016 \\
\hline KU523292.1 & 206.B2 & B2 & Perú & Llamas et al. 2016 \\
\hline KU523293.1 & 207.B2 & B2 & Perú & Llamas et al. 2016 \\
\hline KU523294.1 & 208.B2 & B2 & Perú & Llamas et al. 2016 \\
\hline KU523295.1 & 209.B2b & B2b & Perú & Llamas et al. 2016 \\
\hline KU523296.1 & $210 . \mathrm{B} 2 \mathrm{~b}$ & $\mathrm{~B} 2 \mathrm{~b}$ & Perú & Llamas et al. 2016 \\
\hline KU523297.1 & $211 . \mathrm{B} 2$ & B2 & Perú & Llamas et al. 2016 \\
\hline KU523298.1 & 212.B2b & $\mathrm{B} 2 \mathrm{~b}$ & Perú & Llamas et al. 2016 \\
\hline
\end{tabular}




\begin{tabular}{|c|c|c|c|c|}
\hline Genebank Accession \# & This Study ID & Haplogroup/Haplotype & Geographic Region & Paper \\
\hline KU523299.1 & 213.B2 & B2 & Bolivia & Llamas et al. 2016 \\
\hline KU523300.1 & 214.B2 & B2 & Bolivia & Llamas et al. 2016 \\
\hline KU523301.1 & 215.B2 & B2 & Bolivia & Llamas et al. 2016 \\
\hline KU523302.1 & 216.B2 & B2 & Bolivia & Llamas et al. 2016 \\
\hline KU523303.1 & 217.B2 & B2 & Bolivia & Llamas et al. 2016 \\
\hline KU523308.1 & 218.B2 & B2 & Perú & Llamas et al. 2016 \\
\hline KU523309.1 & 219.B2 & B2 & Perú & Llamas et al. 2016 \\
\hline KU523310.1 & 220.B2 & B2 & Perú & Llamas et al. 2016 \\
\hline KU523311.1 & 221.B2 & B2 & Perú & Llamas et al. 2016 \\
\hline KU523312.1 & $222 . \mathrm{C} 1 \mathrm{~b}$ & $\mathrm{C} 1 \mathrm{~b}$ & Argentina, Llullaillaco & Llamas et al. 2016 \\
\hline KU523313.1 & 223.C1b & $\mathrm{C} 1 \mathrm{~b}$ & Perú & Llamas et al. 2016 \\
\hline KU523314.1 & $224 . \mathrm{C} 1 \mathrm{~b}$ & $\mathrm{C} 1 \mathrm{~b}$ & Perú & Llamas et al. 2016 \\
\hline KU523315.1 & $225 . \mathrm{C} 1 \mathrm{~b}$ & $\mathrm{C} 1 \mathrm{~b}$ & Perú & Llamas et al. 2016 \\
\hline KU523316.1 & $226 . \mathrm{C} 1 \mathrm{~b}$ & $\mathrm{Clb}$ & Perú & Llamas et al. 2016 \\
\hline KU523317.1 & 227.C1b & $\mathrm{Clb}$ & Perú & Llamas et al. 2016 \\
\hline KU523318.1 & $228 . \mathrm{C} 1 \mathrm{~b}$ & $\mathrm{C} 1 \mathrm{~b}$ & Perú & Llamas et al. 2016 \\
\hline KU523319.1 & 229.C1b & $\mathrm{C} 1 \mathrm{~b}$ & Perú & Llamas et al. 2016 \\
\hline KU523320.1 & $230 . \mathrm{Clb}$ & $\mathrm{Clb}$ & Perú & Llamas et al. 2016 \\
\hline KU523321.1 & $231 . \mathrm{C1b}$ & $\mathrm{C} 1 \mathrm{~b}$ & Perú & Llamas et al. 2016 \\
\hline KU523322.1 & 232.Clc & $\mathrm{Clc}$ & Perú & Llamas et al. 2016 \\
\hline KU523323.1 & 233.C1b & $\mathrm{C} 1 \mathrm{~b}$ & Perú & Llamas et al. 2016 \\
\hline KU523324.1 & $234 . \mathrm{C} 1 \mathrm{~b}$ & $\mathrm{C} 1 \mathrm{~b}$ & Perú & Llamas et al. 2016 \\
\hline KU523325.1 & $235 . C 1 b$ & $\mathrm{C} 1 \mathrm{~b}$ & Perú & Llamas et al. 2016 \\
\hline KU523326.1 & $236 . \mathrm{C} 1 \mathrm{~b}$ & $\mathrm{C} 1 \mathrm{~b}$ & Perú & Llamas et al. 2016 \\
\hline KU523327.1 & 237.C1b & $\mathrm{C} 1 \mathrm{~b}$ & Perú & Llamas et al. 2016 \\
\hline KU523328.1 & 238.C1b & $\mathrm{C} 1 \mathrm{~b}$ & Perú & Llamas et al. 2016 \\
\hline KU523329.1 & $239 . \mathrm{Clc}$ & $\mathrm{Clc}$ & Perú & Llamas et al. 2016 \\
\hline KU523330.1 & 240.C1b & $\mathrm{C} 1 \mathrm{~b}$ & Perú & Llamas et al. 2016 \\
\hline KU523331.1 & 241.C1c & $\mathrm{Clc}$ & Perú & Llamas et al. 2016 \\
\hline KU523332.1 & $242 . \mathrm{C} 1 \mathrm{~b}$ & $\mathrm{C} 1 \mathrm{~b}$ & Perú & Llamas et al. 2016 \\
\hline KU523333.1 & 243.C1b & $\mathrm{C} 1 \mathrm{~b}$ & Perú & Llamas et al. 2016 \\
\hline KU523334.1 & 244.C1c & $\mathrm{Clc}$ & Perú & Llamas et al. 2016 \\
\hline KU523335.1 & $245 . \mathrm{Clc}$ & $\mathrm{Clc}$ & Bolivia & Llamas et al. 2016 \\
\hline KU523336.1 & $246 . \mathrm{C1}$ & $\mathrm{Cl}$ & Bolivia & Llamas et al. 2016 \\
\hline KU523337.1 & $247 . \mathrm{C} 1 \mathrm{~b}$ & $\mathrm{C} 1 \mathrm{~b}$ & Bolivia & Llamas et al. 2016 \\
\hline KU523339.1 & 248.C1d & Cld & Perú & Llamas et al. 2016 \\
\hline KU523340.1 & 249.Cld & Cld & Perú & Llamas et al. 2016 \\
\hline KU523341.1 & 250.D1 & D1 & Argentina, Llullaillaco & Llamas et al. 2016 \\
\hline KU523342.1 & 251.D1 & D1 & Perú & Llamas et al. 2016 \\
\hline KU523343.1 & 252.D & $\mathrm{D}$ & Perú & Llamas et al. 2016 \\
\hline KU523344.1 & 253.D1 & D1 & Perú & Llamas et al. 2016 \\
\hline KU523345.1 & 254.D & $D$ & Perú & Llamas et al. 2016 \\
\hline KU523346.1 & 255.D1 & D1 & Perú & Llamas et al. 2016 \\
\hline KU523347.1 & 256.D1 & D1 & Perú & Llamas et al. 2016 \\
\hline KU523348.1 & 257.D1 & D1 & Perú & Llamas et al. 2016 \\
\hline KU523349.1 & 258.D1 & D1 & Argentina, Arroyo Seco & Llamas et al. 2016 \\
\hline KU523350.1 & 259.D1 & D1 & Perú & Llamas et al. 2016 \\
\hline
\end{tabular}


Supplementary Table S2. Data Set of 174 Complete Mitochondrial DNA (mtDNA) Sequences from Modern Humans of North America Used in This Study

\begin{tabular}{|c|c|c|c|}
\hline Genbank Accession \# & Haplogroup/Haplotype & Geographic Region & Paper \\
\hline KC710999 & A2a & Alaska & Achilli et al. 2013 \\
\hline KC711000 & A2a3 & Groenlandia & Achilli et al. 2013 \\
\hline KC711001 & A2a4 & Nuevo México & Achilli et al. 2013 \\
\hline KC711002 & $\mathrm{A} 2 \mathrm{a} 4$ & Nuevo México & Achilli et al. 2013 \\
\hline KC711003 & A2a4 & Arizona & Achilli et al. 2013 \\
\hline KC711004 & $\mathrm{A} 2 \mathrm{a} 4$ & Nuevo México & Achilli et al. 2013 \\
\hline KC711005 & A2a4 & Chihuhua, México & Achilli et al. 2013 \\
\hline KC711006 & $\mathrm{A} 2 \mathrm{a} 4$ & Chihuhua, México & Achilli et al. 2013 \\
\hline KC711007 & $\mathrm{A} 2 \mathrm{a} 4$ & Arizona/ Nuevo México & Achilli et al. 2013 \\
\hline KC711008 & A2a & noroeste de Canadá & Achilli et al. 2013 \\
\hline KC711009 & A2a5 & Nuevo México & Achilli et al. 2013 \\
\hline KC711010 & A2a5 & Texas & Achilli et al. 2013 \\
\hline KC711011 & A2a5 & California & Achilli et al. 2013 \\
\hline KC711012 & A2a5 & Arizona & Achilli et al. 2013 \\
\hline KC711013 & A2a5 & Arizona & Achilli et al. 2013 \\
\hline KC711014 & A2a5 & California & Achilli et al. 2013 \\
\hline KC711015 & A2a5 & Arizona & Achilli et al. 2013 \\
\hline KC711016 & A2a5 & Nuevo México & Achilli et al. 2013 \\
\hline KC711017 & A2a5 & Canadá & Achilli et al. 2013 \\
\hline KC711018 & A2a5 & noroeste de Canadá & Achilli et al. 2013 \\
\hline KC711019 & A2a5 & Nuevo México & Achilli et al. 2013 \\
\hline KC711020 & A2a5 & Nuevo México & Achilli et al. 2013 \\
\hline KC711021 & B2a & noroeste de Canadá & Achilli et al. 2013 \\
\hline KC711022 & B2a & Chihuhua, México & Achilli et al. 2013 \\
\hline KC711023 & B2ala & México & Achilli et al. 2013 \\
\hline KC711024 & B2a1a & Chihuhua, México & Achilli et al. 2013 \\
\hline KC711025 & B2alb & Chihuhua, México & Achilli et al. 2013 \\
\hline KC711026 & B2a1 & Nuevo México & Achilli et al. 2013 \\
\hline KC711027 & B2a1 & México & Achilli et al. 2013 \\
\hline KC711028 & $\mathrm{B} 2 \mathrm{a} 2$ & Nuevo México & Achilli et al. 2013 \\
\hline KC711029 & B2a2 & Colorado & Achilli et al. 2013 \\
\hline KC711030 & B2a2 & Colorado & Achilli et al. 2013 \\
\hline KC711031 & B2a3 & Chihuhua, México & Achilli et al. 2013 \\
\hline KC711032 & B2a3 & Durango, México & Achilli et al. 2013 \\
\hline KC711033 & B2a4a & Sinaloa, México & Achilli et al. 2013 \\
\hline KC711034 & B2a4a1 & Chihuhua, México & Achilli et al. 2013 \\
\hline KC711035 & B2a4al & Jalisco, México & Achilli et al. 2013 \\
\hline KC711036 & B2a4a1 & Durango, México & Achilli et al. 2013 \\
\hline KC711037 & B2a5 & Arizona & Achilli et al. 2013 \\
\hline KC711038 & B2a5 & Utah & Achilli et al. 2013 \\
\hline KC711039 & B2a5 & Arizona & Achilli et al. 2013 \\
\hline EU597533 & $\mathrm{Clc}$ & Pima, México & Hartmann et al. 2008 \\
\hline EU597545 & $\mathrm{C} 1 \mathrm{~b}$ & Pima, México & Hartmann et al. 2008 \\
\hline EU597557 & $\mathrm{Clb}$ & Pima, México & Hartmann et al. 2008 \\
\hline FJ168729 & D4h3a3 & Nuevo León, México & Perego et al. 2009 \\
\hline FJ168730 & D4h3a3 & California, Estados Unidos & Perego et al. 2009 \\
\hline FJ168731 & D4h3a3 & Chihuhua, México & Perego et al. 2009 \\
\hline FJ168732 & D4h3a3 & Chihuhua, México & Perego et al. 2009 \\
\hline FJ168733 & D4h3a3 & Chihuhua, México & Perego et al. 2009 \\
\hline FJ168734 & D4h3a3 & Tarahumara, México & Perego et al. 2009 \\
\hline FJ168742 & D4h3a & Veracruz, México & Perego et al. 2009 \\
\hline
\end{tabular}




\begin{tabular}{|c|c|c|c|}
\hline Genbank Accession \# & Haplogroup/Haplotype & Geographic Region & Paper \\
\hline FJ168745 & D4h3a & Sonora, México & Perego et al. 2009 \\
\hline FJ168746 & D4h3a & Chihuhua, México & Perego et al. 2009 \\
\hline FJ168753 & D4h3a & San Luis Potosi, México & Perego et al. 2009 \\
\hline FJ168755 & D4h3a & California, Estados Unidos & Perego et al. 2009 \\
\hline HM107306 & C1d & Tamaulipas, México & Perego et al. 2010 \\
\hline HM107307 & C1d & Guanajuato, México & Perego et al. 2010 \\
\hline HM107308 & C1d & Chihuahua, México & Perego et al. 2010 \\
\hline HM107318 & Cld1al & Oklahoma, Estados Unidos & Perego et al. 2010 \\
\hline HM107319 & Cld1al & Montana, Estados Unidos & Perego et al. 2010 \\
\hline HM107320 & Cld1al & Quebec, Canadá & Perego et al. 2010 \\
\hline HM107321 & Cld1al & Zacatecas, México & Perego et al. 2010 \\
\hline HM107322 & C1d1a & Sonora, México & Perego et al. 2010 \\
\hline HM107334 & $\mathrm{C} 1 \mathrm{~d} 1 \mathrm{c}$ & Oaxaca, México & Perego et al. 2010 \\
\hline HM107335 & $\mathrm{C} 1 \mathrm{~d} 1 \mathrm{cl}$ & Texas, Estados Unidos & Perego et al. 2010 \\
\hline HM107336 & $\mathrm{C} 1 \mathrm{~d} 1 \mathrm{c}$ & Texas, Estados Unidos & Perego et al. 2010 \\
\hline HM107337 & C1d1c & Michigan, Estados Unidos & Perego et al. 2010 \\
\hline HM107364 & C1d1 & Oklahoma, Estados Unidos & Perego et al. 2010 \\
\hline DQ282387 & A2 & Estados Unidos & Just et al. 2008 \\
\hline DQ282388 & $\mathrm{A} 2$ & Estados Unidos & Just et al. 2008 \\
\hline DQ282389 & A2 & Estados Unidos & Just et al. 2008 \\
\hline DQ282390 & A2 & Estados Unidos & Just et al. 2008 \\
\hline DQ282391 & A2 & Estados Unidos & Just et al. 2008 \\
\hline DQ282392 & A2 & Estados Unidos & Just et al. 2008 \\
\hline DQ282393 & $\mathrm{A} 2$ & Estados Unidos & Just et al. 2008 \\
\hline DQ282394 & A2 & Estados Unidos & Just et al. 2008 \\
\hline DQ282395 & $\mathrm{A} 2$ & Estados Unidos & Just et al. 2008 \\
\hline DQ282396 & A2 & Estados Unidos & Just et al. 2008 \\
\hline DQ282397 & $\mathrm{A} 2$ & Estados Unidos & Just et al. 2008 \\
\hline DQ282398 & A2 & Estados Unidos & Just et al. 2008 \\
\hline DQ282399 & $\mathrm{A} 2$ & Estados Unidos & Just et al. 2008 \\
\hline DQ282400 & $\mathrm{A} 2$ & Estados Unidos & Just et al. 2008 \\
\hline DQ282401 & A2 & Estados Unidos & Just et al. 2008 \\
\hline DQ282402 & $\mathrm{A} 2$ & Estados Unidos & Just et al. 2008 \\
\hline DQ282403 & A2 & Estados Unidos & Just et al. 2008 \\
\hline DQ282404 & A2 & Estados Unidos & Just et al. 2008 \\
\hline DQ282405 & A2 & Estados Unidos & Just et al. 2008 \\
\hline DQ282406 & A2 & Estados Unidos & Just et al. 2008 \\
\hline DQ282407 & A2 & Estados Unidos & Just et al. 2008 \\
\hline DQ282408 & A2 & Estados Unidos & Just et al. 2008 \\
\hline DQ282409 & A2 & Estados Unidos & Just et al. 2008 \\
\hline DQ282410 & $\mathrm{A} 2$ & Estados Unidos & Just et al. 2008 \\
\hline DQ282411 & A2 & Estados Unidos & Just et al. 2008 \\
\hline DQ282412 & A2 & Estados Unidos & Just et al. 2008 \\
\hline DQ282413 & A2 & Estados Unidos & Just et al. 2008 \\
\hline DQ282414 & A2 & Estados Unidos & Just et al. 2008 \\
\hline DQ282415 & A2 & Estados Unidos & Just et al. 2008 \\
\hline DQ282416 & A2 & Estados Unidos & Just et al. 2008 \\
\hline DQ282417 & A2 & Estados Unidos & Just et al. 2008 \\
\hline DQ282418 & $\mathrm{A} 2$ & Estados Unidos & Just et al. 2008 \\
\hline DQ282419 & A2 & Estados Unidos & Just et al. 2008 \\
\hline DQ282420 & A2 & Estados Unidos & Just et al. 2008 \\
\hline DQ282421 & A2 & Estados Unidos & Just et al. 2008 \\
\hline DQ282422 & A2 & Estados Unidos & Just et al. 2008 \\
\hline DQ282423 & A2 & Estados Unidos & Just et al. 2008 \\
\hline
\end{tabular}




\begin{tabular}{|c|c|c|c|}
\hline Genbank Accession \# & Haplogroup/Haplotype & Geographic Region & Paper \\
\hline DQ282424 & $\mathrm{A} 2$ & Estados Unidos & Just et al. 2008 \\
\hline DQ282425 & A2 & Estados Unidos & Just et al. 2008 \\
\hline DQ282426 & A2 & Estados Unidos & Just et al. 2008 \\
\hline DQ282427 & A2 & Estados Unidos & Just et al. 2008 \\
\hline DQ282428 & $\mathrm{A} 2$ & Estados Unidos & Just et al. 2008 \\
\hline DQ282429 & $\mathrm{A} 2$ & Estados Unidos & Just et al. 2008 \\
\hline DQ282430 & A2 & Estados Unidos & Just et al. 2008 \\
\hline DQ282431 & A2 & Estados Unidos & Just et al. 2008 \\
\hline DQ282432 & A2 & Estados Unidos & Just et al. 2008 \\
\hline DQ282433 & A2 & Estados Unidos & Just et al. 2008 \\
\hline DQ282434 & B2 & Estados Unidos & Just et al. 2008 \\
\hline DQ282435 & B2 & Estados Unidos & Just et al. 2008 \\
\hline DQ282436 & B2 & Estados Unidos & Just et al. 2008 \\
\hline DQ282437 & B2 & Estados Unidos & Just et al. 2008 \\
\hline DQ282438 & B2 & Estados Unidos & Just et al. 2008 \\
\hline DQ282439 & B2 & Estados Unidos & Just et al. 2008 \\
\hline DQ282440 & B2 & Estados Unidos & Just et al. 2008 \\
\hline DQ282441 & B2 & Estados Unidos & Just et al. 2008 \\
\hline DQ282442 & B2 & Estados Unidos & Just et al. 2008 \\
\hline DQ282443 & B2 & Estados Unidos & Just et al. 2008 \\
\hline DQ282444 & B2 & Estados Unidos & Just et al. 2008 \\
\hline DQ282445 & B2 & Estados Unidos & Just et al. 2008 \\
\hline DQ282446 & B2 & Estados Unidos & Just et al. 2008 \\
\hline DQ282447 & $\mathrm{Cl}$ & Estados Unidos & Just et al. 2008 \\
\hline DQ282448 & $\mathrm{C} 1$ & Estados Unidos & Just et al. 2008 \\
\hline DQ282449 & $\mathrm{Cl}$ & Estados Unidos & Just et al. 2008 \\
\hline DQ282450 & $\mathrm{Cl}$ & Estados Unidos & Just et al. 2008 \\
\hline DQ282451 & $\mathrm{C} 1$ & Estados Unidos & Just et al. 2008 \\
\hline DQ282452 & $\mathrm{Cl}$ & Estados Unidos & Just et al. 2008 \\
\hline DQ282453 & $\mathrm{C} 1$ & Estados Unidos & Just et al. 2008 \\
\hline DQ282454 & $\mathrm{Cl}$ & Estados Unidos & Just et al. 2008 \\
\hline DQ282455 & $\mathrm{C} 1$ & Estados Unidos & Just et al. 2008 \\
\hline DQ282456 & $\mathrm{C} 1$ & Estados Unidos & Just et al. 2008 \\
\hline DQ282457 & $\mathrm{Cl}$ & Estados Unidos & Just et al. 2008 \\
\hline DQ282458 & $\mathrm{Cl}$ & Estados Unidos & Just et al. 2008 \\
\hline DQ282459 & $\mathrm{Cl}$ & Estados Unidos & Just et al. 2008 \\
\hline DQ282460 & $\mathrm{C} 1$ & Estados Unidos & Just et al. 2008 \\
\hline DQ282461 & $\mathrm{C} 1$ & Estados Unidos & Just et al. 2008 \\
\hline DQ282462 & $\mathrm{Cl}$ & Estados Unidos & Just et al. 2008 \\
\hline DQ282463 & $\mathrm{Cl}$ & Estados Unidos & Just et al. 2008 \\
\hline DQ282464 & $\mathrm{Cl}$ & Estados Unidos & Just et al. 2008 \\
\hline DQ282465 & $\mathrm{C} 1$ & Estados Unidos & Just et al. 2008 \\
\hline DQ282466 & $\mathrm{C} 1$ & Estados Unidos & Just et al. 2008 \\
\hline DQ282467 & $\mathrm{Cl}$ & Estados Unidos & Just et al. 2008 \\
\hline DQ282468 & $\mathrm{Cl}$ & Estados Unidos & Just et al. 2008 \\
\hline DQ282469 & $\mathrm{C} 1$ & Estados Unidos & Just et al. 2008 \\
\hline DQ282470 & $\mathrm{C} 1$ & Estados Unidos & Just et al. 2008 \\
\hline DQ282471 & $\mathrm{C} 1$ & Estados Unidos & Just et al. 2008 \\
\hline DQ282472 & $\mathrm{C} 1$ & Estados Unidos & Just et al. 2008 \\
\hline DQ282473 & $\mathrm{Cl}$ & Estados Unidos & Just et al. 2008 \\
\hline DQ282474 & $\mathrm{Cl}$ & Estados Unidos & Just et al. 2008 \\
\hline DQ282475 & $\mathrm{C} 1$ & Estados Unidos & Just et al. 2008 \\
\hline DQ282476 & $\mathrm{C} 1$ & Estados Unidos & Just et al. 2008 \\
\hline DQ282477 & D1 & Estados Unidos & Just et al. 2008 \\
\hline
\end{tabular}




\begin{tabular}{|c|c|l|l|}
\hline Genbank Accession \# & Haplogroup/Haplotype & \multicolumn{1}{|c|}{ Geographic Region } & \multicolumn{1}{c|}{ Paper } \\
\hline DQ282478 & D1 & Estados Unidos & Just et al. 2008 \\
\hline DQ282479 & D1 & Estados Unidos & Just et al. 2008 \\
\hline DQ282480 & D1 & Estados Unidos & Just et al. 2008 \\
\hline DQ282481 & D1 & Estados Unidos & Just et al. 2008 \\
\hline DQ282482 & D1 & Estados Unidos & Just et al. 2008 \\
\hline DQ282483 & D1 & Estados Unidos & Just et al. 2008 \\
\hline DQ282484 & D1 & Estados Unidos & Just et al. 2008 \\
\hline DQ282485 & D1 & Estados Unidos & Just et al. 2008 \\
\hline DQ282486 & D1 & Estados Unidos & Just et al. 2008 \\
\hline DQ282487 & D1 & Estados Unidos & Just et al. 2008 \\
\hline KU523304 & B2 & Estados Unidos & Just et al. 2008 \\
\hline KU523305 & B2 & Estados Unidos & Just et al. 2008 \\
\hline KU523306 & B2 & Estados Unidos & Just et al. 2008 \\
\hline KU523307 & B2 & Estados Unidos & Just et al. 2008 \\
\hline KU523338 & C1b & Estados Unidos & Just et al. 2008 \\
\hline
\end{tabular}

